\title{
Macroprudential Bank Capital Regulation in a Competitive Financial System*
}

\author{
Milton Harris ${ }^{\dagger}$ \\ Christian C. Opp $\ddagger$ \\ Marcus M. Opp ${ }^{\S}$
}

January 9, 2015

\begin{abstract}
We propose a tractable general equilibrium framework to analyze the effectiveness of bank capital regulations when banks face competition from public markets. Our analysis shows that increased competition can not only render previously optimal bank capital regulations ineffective but also imply that, over some ranges, increases in capital requirements cause more banks to engage in value-destroying risk-shifting. Our model generates a set of novel implications that highlight the dependencies between optimal bank capital regulation and the comparative advantages of various players in the financial system.
\end{abstract}

${ }^{*}$ We are grateful to Anat Admati, Michael Brennan, Elena Carletti, Sam Lee, George Pennachi, Giorgia Piacentino, Matt Spiegel and Jeremy Stein for thoughtful discussions of earlier drafts of this paper as well as Valerie Shen and Peter DeMarzo for helpful comments. In addition, we thank seminar participants at the NBER SI 2014, the Berkeley-Stanford joint seminar, the University of Chicago, the Bundesbank, the Federal Reserve Bank of New York and the Federal Reserve Board of Governors.

${ }^{\dagger}$ University of Chicago, Booth School of Business, e-mail: milt@chicagobooth.edu. Professor Harris thanks the Center for Research in Security Prices at the University of Chicago Booth School of Business for financial support.

${ }^{\ddagger}$ University of Pennsylvania, The Wharton School, email: opp@wharton.upenn.edu. Research support from the Rodney White Center for Financial Research and the Wharton School Dean's Research Fund is gratefully acknowledged.

$\S$ University of California, Berkeley (Haas), email: mopp@haas.berkeley.edu. 


\section{Introduction}

The recent financial crisis has put bank capital regulation at the forefront of political and academic debates. A main concern motivating capital regulation is banks' incentive to take excessive leverage and risk when the government is expected to intervene in times of financial turmoil and support banks in distress. As a result, many academics and politicians call for substantial increases in equity capital requirements.11 Opponents of such changes, however, highlight potential negative ramifications, in particular, reductions in bank lending that could reduce economic growth if borrowers lack good alternatives to bank finance.

In this paper we argue that these alternative sources of finance can have important implications for the effectiveness of bank capital requirements, above and beyond the notion that, as potential substitutes, they can mitigate the negative fallout effects of reductions in bank lending. Using a tractable general equilibrium model we study how specifically public capital markets, an important alternative source of finance in the US economy ${ }^{2}$ influence the effectiveness of system-wide changes in bank capital requirements.

In contrast to the standard partial equilibrium intuition that higher capital requirements lower banks' risk-taking due to greater skin-in-the-game, our model reveals that the opposite may be true - over some ranges, increases in capital requirements can cause more banks to engage in value-destroying risk-shifting, implying a non-monotonic relationship between capital requirements and risk-taking by the average bank. Our model further predicts that increases in competition from public capital markets can render existing capital regulations ineffective. Overall, our results highlight the need for macroprudential approaches to regulation that explicitly account for general equilibrium effects and adjust capital requirements in response to changes in the competitive landscape of financial markets.

Our model starts with the premise that governments face a time-inconsistency problem - they are unable to refrain from supporting distressed banks when support is ex post welfare-enhancing ${ }^{3}$ Such ex-post bailouts imply that the Modigliani-Miller theorem is violated and banks may have incentives to takes excessive leverage and risk. To mitigate this

\footnotetext{
${ }^{1}$ See, e.g., Admati, DeMarzo, Hellwig, and Pfleiderer (2011).

${ }^{2}$ See, e.g., Becker and Ivashina (2014) for empirical evidence on firms' substitution between bank and public debt in response to changes in the supply of bank credit.

${ }^{3}$ Government support can take various forms, such as asset purchase programs, monetary policy changes, or outright bail-outs of banks' debt holders.
} 
inefficient behavior, the government imposes minimum equity capital ratio requirements. Banks, however, do not operate in isolation when responding to regulation, but instead compete with each other and public market investors that can also supply capital. On the demand side are borrowers of various types that have projects that differ in their riskiness and the social surplus they generate. Throughout we refer to good (bad) borrowers as firms with projects that create (destroy) social surplus. In our general equilibrium setting both loan terms and quantities adjust endogenously.

In this production economy, banks have an incentive to intentionally fund risky, and potentially bad, borrowers by choosing high leverage to transfer downside risks to the government. The bonds of risky issuers exhibit rational overpricing as implicitly insured banks become the marginal investors of these assets and bid prices up, potentially to the point where the cross-section of equilibrium yields is completely uninformative about underlying default risk. Higher capital requirements are effective in lowering the profitability of these risk-taking strategies but can also reduce banks' funding capacity - banks' balance sheets contract in response to higher equity ratio requirements whenever the cost of raising outside equity exceeds the banks' marginal return on equity in equilibrium.

Shareholder value maximization further dictates that banks, when contracting their balance sheets, shed their lowest-profitability borrowers first. Banks' profits from various borrower types are, however, generally not aligned with the social surplus these borrowers generate. In particular, competition implies that bank profits reflect both banks' real efficiency advantages vis-à-vis public markets and artificial advantages due to government bailouts - "cheap" deposit finance is available to banks even when they take large risks.

As a result, when the banking sector, represented by a continuum of banks, faces higher capital requirements and reduced funding capacity, it responds by dropping good borrowers if, at the margin, these borrowers are less privately profitable than bad ones. Banks that previously funded good borrowers then switch to bad, high-risk borrowers, stepping in for other banks that already funded bad borrowers but now have more limited funding capacity. System-wide increases in capital requirements can thus increase risk-taking and distress risk at the individual bank-level and for the average bank, a prediction that would not emerge in partial equilibrium.

Paradoxically, increased efficiency of public markets can be the initial trigger of this deliberate selection of bad borrowers by banks. As informed public market investors, who bear the full downside of lending to risky borrowers, can only compete with banks for borrowers that generate weakly positive surplus, they affect banks' portfolio choice in an 
asymmetric - and socially adverse - way. Their financing offers only limit banks' profits from lending to good borrowers, thus increasing the relative profitability of bad borrowers. More efficient public markets thus increase banks' incentives to focus on risky, surplusdestroying borrowers whenever funding capacity constraints are binding. No matter what caused constraints to bind in the first place - regulatory changes, macroeconomic shocks that reduced the banking sector's total equity, or changes in borrower characteristics the same logic applies.

Despite the fact that existing capital requirements may become ineffective after increases in competition from public markets, they are, by no means, a lost cause. Our model predicts that for capital ratio requirements above an endogenous threshold, the skin-in-the-game effect is always strong enough to ensure that funding surplus-destroying borrowers is privately suboptimal for banks. This threshold level generally depends on the relative funding efficiency of public markets and banks. Increasing regulatory capital requirements to this threshold may, however, also constrain banks' lending capacity so much that not all good borrowers in the economy are funded by banks, leading to underinvestment or less efficient funding through public capital markets. Nonetheless, these results imply that substantial capital requirements may be warranted to achieve a reduction in risk-taking by banks, in particular when fierce competition from public markets depresses banks' profits from funding socially valuable projects.

Equity issuances that lead to increases in banks' equity levels are, however, not always welfare enhancing either. Absent increases in equity ratio requirements, banks may have incentives to lever up against additional equity to increase the magnitude of their activities while leaving their leverage and riskiness unaffected. In this case, even more substantial capital ratio requirements may be needed to curtail banks' risk-taking. Related empirical evidence suggests that commercial banks manage their balance sheets to maintain leverage ratios: after a positive shock to their assets in booms and a corresponding increase in their equity, commercial banks tend to raise additional debt to maintain target leverage ratios (see Figure 3 in Adrian and Shin, 2010). As a result, in booms, banks may just use the increases in equity to expand their balance sheets and the scale of their risk-taking activities, which is consistent with the notion of aggregate expansions in risk-taking during booms when banks' equity values go up.

In light of the highlighted global non-monotonicities in bank risk-taking it is important to note that our model does not unconditionally predict an increase in risk-taking by banks in response to higher capital requirements, but instead highlights conditions under which 
some ranges of system-wide increases in capital requirements can be insufficient, or even counterproductive. Specifically, increases in capital requirements create adverse effects when the following two conditions are met: (1) at the initial level of capital requirements banks could, at the margin, extract more rents from funding another bad borrower than from funding another good borrower; (2) banks are quantity-constrained in the sense that equity issuance costs exceed the profitability of the marginal borrower and equity capital ratio constraints are binding. Given these two conditions are met, a marginal system-wide increase in capital requirements will lead to a contraction in the banking sector's balance sheet and a focus on lending to bad borrowers at the expense of good borrowers.

Competition matters for the effectiveness of capital requirements as both the first and the second condition are more likely to be met when banks face increased competition for good borrowers from public capital markets. In the time series, our model therefore predicts that increasing competition from public markets for borrowers that were historically bank-financed would increase banks' incentives to focus on bad borrowers with high systematic risk when constrained. This prediction is reminiscent of a popular argument that, over time, increased competition caused banks to "reach for yield" in an effort to stay profitable (see, e.g., Becker and Ivashina, 2013). Further, this effect may imply that, relative to past decades, significantly larger equity ratio requirements may be needed nowadays to ensure that banks' incentives are adequate and risk-shifting is prevented. The prediction that increased competition from public capital markets can reduce the effectiveness of capital regulations and cause banks to shift toward risky, bad borrowers is also consistent with events preceding Japan's financial crises in the 1990s (see Hoshi and Kashyap, 1999, 2001). Dramatic deregulation leading up to the "Japanese Big Bang" allowed large corporations to quickly switch from banks to capital market financing. Japanese banks responded to this new competition by shifting their investments toward small businesses and real estate. Higher exposures to systematically risky, low quality borrowers then fueled the problems of many Japanese banks.

When considering the empirical content of our model it is important to emphasize that our model does not predict that if an individual bank's capital requirements are increased this bank will increase its risk-taking. In fact, our model predicts the opposite: the bank will weakly lower its risk-taking in that case. Regulatory changes for a broad set of financial institutions and corresponding general equilibrium effects are thus key for our predictions.

Our predictions for the banking sector should further not be viewed as applying literally only to registered commercial banks but rather more generally to levered financial 
institutions that potentially receive government support in times of financial turmoil. As witnessed during the recent financial crisis, massive government support was provided not only to traditional banks, but also to investment banks, insurance companies, and other institutions in the shadow banking system, in particular money market mutual funds.$_{4}^{4}$ Further, in practice, banks may move part of their assets and liabilities off the regulated balance-sheet and into the less stringently regulated shadow banking system in an effort to circumvent regulations. These shadow banking activities, however, typically involve some form of recourse and thus still ultimately expose the original bank's balance sheet to potential losses, some of which the government might absorb during a financial crisis. On the other hand, public market investors in our model refer to investors that are less likely to be subject to government support, such as bond mutual fund investors.

Although our paper also addresses optimal regulatory regimes, it primarily focuses on the positive implications of changes in capital requirements. That is, we trace out implications of all potential levels of capital requirements. This positive analysis acknowledges the existence of relevant forces beyond our parsimonious framework, such as political economy frictions, which might bias implemented regulations (for example, to the favor of bankers).

Moreover, our analysis considers an economy where regulators do not have access to contractible variables that fully identify both the riskiness and the social surplus of projects that banks fund. Although we agree that using informative conditioning variables (and corresponding risk weights) can be helpful in practice, a lack of perfect measures implies residual dispersion that can give rise to moral hazard, which is the problem we study. Empirical evidence provided in the existing literature documents the imprecision and bias of risk measures used by regulators: Banks and insurance companies systematically targeted risky securities within a given risk class in the years leading up to the 2008/09 financial crisis, behavior that is consistent with the asset choice moral hazard at the heart of our

${ }^{4}$ For example, on September 19, 2008 the US Treasury announced a "Temporary Guarantee Program for Money Market Funds," which offered a US government guarantee on all existing investments in participating money market funds. 
paper. ${ }^{5}$

Related literature. To the best of our knowledge, this paper is the first to provide a general equilibrium framework that allows an analysis of the effects of bank capital regulations when banks and public market investors compete in financial markets. Although several recent papers on bank capital regulation also feature general equilibrium settings, these papers abstract from competition by non-bank investors and typically assume that banks either have monopolistic access to certain borrowers or compete only amongst each other (see, e.g., Begenau, 2013, Nguyen, 2014). As a result, those papers do not find the non-monotonic effect of capital requirements on banks' risk-taking that we highlight in this paper.

Although bank deposits also have a socially beneficial role in our model in that they can be monitored more easily than other claims, our paper is primarily concerned with the dangers of excessive bank leverage. A large literature following Diamond and Dybvig (1983) and Gorton and Pennacchi (1990) argues that bank deposits are special. Banks can provide liquidity services via deposits, i.e., maturity transformation and produce informationinsensitive claims. In this spirit, DeAngelo and Stulz (2013) argue that stringent capital requirements may impede the banking sector's ability to produce valuable liquid claims, causing potentially important social costs that need be considered in the overall tradeoff calculation. In our model, a parameter that captures banks' comparative advantage relative to public market investors may also be interpreted in terms of liquidity provision.

Further, a large set of papers in the micro-theory literature analyzes bank capital regulation but abstracts from the general equilibrium effects that are present in our model (see, e.g., Pennacchi, 2006, Mehran, Acharya, and Thakor, 2013). Harris and Raviv (2014) also show that, under some circumstances, increasing capital requirements reduces welfare.

${ }^{5}$ For example, evidence in Erel, Nadauld, and Stulz (2013) suggests that large banks retained the highlyrated, but systematically risky, tranches of securitizations on their balance sheets due to these securities' low risk-weighting. Prior to the crisis, large banks could further enjoy even lower effective capital charges by funding securities off-balance sheet, in asset-backed commercial paper conduits. Acharya, Schnabl, and Suarez (2013) document that credit lines backing the commercial paper were de facto credit guarantees but qualified as liquidity guarantees for regulatory capital purposes, implying much lower capital charges. Iannotta and Pennachi (2014) show that since credit ratings do not accurately reflect the systematic risk exposures of corporate bonds, insured financial institutions can benefit substantially from selecting those corporate bonds that have the highest systematic risk in a given ratings class. Consistent with this argument, Becker and Ivashina (2013) find that, for a given regulatory rating class, insurance companies own a higher proportion of corporate bonds that have above average credit spreads in a given rating class than mutual funds and pension funds (which are not subject to regulatory capital requirements). This reaching-for-yield behavior is more pronounced among insurance companies with more binding regulatory capital constraints and leads to greater exposures to systematic risk. 
The result is driven by the interaction between the regulator's desire to prevent excessive risk-taking by banks, while, at the same time, ensure that they disclose early on when they are in trouble. Plantin (2014) analyzes optimal bank capital regulation in the presence of shadow banking activities, but considers a partial equilibrium model that abstracts from competition. In his setting banks can engage in shadow banking activities as a response to stringent regulation (see also Ordonez (2014), Moreira and Savov (2013)). Consequently, relaxing capital requirements may be beneficial, as it reduces banks' incentives to circumvent regulation $\sqrt{6}$ Gornall and Strebulaev (2013) develop a quantitative trade-off model of bank capital structure in which only highly levered banks can pass on tax benefits of debt to firms. Allen, Carletti, and Marquez (2011) present a model of bank moral hazard that justifies why banks might hold capital in excess of regulatory minimums and refrain from changing their holdings in response to regulatory changes. In their model banks can find it optimal to use costly capital rather than the interest rate on the loan to guarantee monitoring because it allows higher borrower surplus.

Our paper is organized as follows. We discuss the structure of the economy and our modeling assumptions in Section 2. In Section 3, we present the general results of the paper. In Section 4, we illustrate these general implications with specific examples. Section 5 discusses extensions and robustness of our general analysis. Section 6 concludes.

\section{Model setup}

We consider a discrete-state, incomplete-markets economy with two dates, 0 and 1 . At date 1 , the aggregate state of the world $s \in S$ is realized. The ex-ante probability of state $s$ is denoted by $p_{s}>0$. The economy consists of firms, public market investors, banks, and a regulator, which we describe in detail below. All agents in the economy are risk-neutral and discount their respective payoffs at a discount rate of 0 .

\section{$2.1 \quad$ Firms}

There is a continuum of firms of measure one, indexed by $i \in \Omega=[0,1]$. Each firm $i$ is owned by a cashless entrepreneur who has access to a project that requires an upfront

${ }^{6}$ In an empirical study, Kisin and Manela (2013) estimate the shadow cost of existing capital regulation by exploiting a regulatory loophole that allowed banks to bypass capital requirements. They find that the compliance costs of pre-crisis regulation are small. 
investment of 1 at time 0 and generates project-specific, state-contingent cash flows $C_{s}(i) \geq$ 0 at date 1 . An investment in project $i$ thus generates expected surplus of

$$
N P V(i)=\mathbb{E}\left[C_{s}(i)\right]-1
$$

Entrepreneurs may obtain financing from banks and public market investors, all of which observe the firms' cash flow prospects perfectly. $]^{7}$ Entrepreneurs can, however, divert all cash flows from the project unless they are monitored by investors, as described in more detail below. While we do not restrict the set of securities that firms can issue to public market investors, we assume that firms can only obtain (senior) debt from banks. This assumption does not only match empirical evidence, it also simplifies exposition substantially. 8

\section{$2.2 \quad$ Public market investors}

There is a continuum of public market investors of measure 1 . We assume that these agents behave competitively and have sufficient financial wealth to finance all projects in the economy. At date 0, public market investors have access to the following investment opportunities: (1) bank deposits, (2) securities issued by firms and banks in public markets, and (3) a storage technology with zero interest.

In order to avoid cash flow diversion by issuers, public market investors have to monitor the issuer. Monitoring leads to a deadweight cost of $\frac{c_{k}}{1+c_{k}} \geq 0$ per unit of expected cash flows that a project or security generates. We allow the cost, $c_{k}$, to vary across securities $k$ (see e.g., Hennessy and Whited (2007) for empirical evidence on differences between the cost of raising equity and debt) $!^{9}$ These costs are incurred before the aggregate state is

${ }^{7}$ Similar to Parlour and Rajan (2001), our model thus abstracts from asymmetric information in the financing process (see, e.g., Stiglitz and Weiss (1981)). One could envision an alternative setting where public market investors are less informed than banks. In a previous version of this paper, we considered a model where public market investors were uninformed and had to rely on ratings provided by a strategic credit rating agency. This more complex model yielded qualitatively similar results.

8 This restriction on the security space can be endogenized as an equilibrium outcome under optimal regulation. If the regulator can distinguish between banks' investments in corporate equity and corporate debt, she would optimally impose higher capital requirements on equity positions since equity is (weakly) riskier. In practice, U.S. banks are subject to a risk-weight of $300 \%$ for publicly traded stocks and $400 \%$ for non-publicly traded equity exposures under Basel III.

${ }^{9}$ While we refer to these additional cost as monitoring cost, qualitatively similar effects could arise in the presence of other frictions in public markets, such as higher loan collection cost, reduced screening incentives, or duplication of effort. 
realized at date 1 . Risk neutrality and a discount rate of 0 imply that a public market investor values a security $k$ with state-contingent cash flow $C F_{s}(k)$ as

$$
P V_{P}=\frac{\mathbb{E}\left[C F_{s}(k)\right]}{1+c_{k}} .
$$

In brief, public markets effectively provide a firm with a type-dependent outside option of $\max \{N P V(i)-c, 0\}$, where $c \equiv \min _{k} c_{k}$ represents the cheapest source of public market financing 10

\subsection{Banks}

There is a measure one of competitive, ex-ante identical bankers (also referred to as banks) ${ }^{11}$ We omit bank-specific subscripts $j$ for notational convenience whenever possible.

Shareholders' equity and deposits. Each bank has initial wealth $\bar{E}_{0}>0$ in the form of cash at time 0 , where $\bar{E}_{0}$ can be interpreted as the book value of inside equity. Banks can raise outside equity $\Delta_{E} \geq 0$ from public capital markets ${ }^{12}$ Equity issuances are subject to the same cash flow diversion problem as outlined for entrepreneurs. Thus, in order to raise funds of $\Delta_{E}$ from outside investors, banks need to promise a share of total equity such that the market value of cash flows is $\Delta_{E}\left(1+c_{E}\right)$. Given $\Delta_{E}$, the book value of bank equity is then:

$$
E_{0}=\bar{E}_{0}+\Delta_{E}
$$

Banks can further raise deposits $D_{0}$ at the deposit rate $r_{D} \geq 0$. The deposit rate $r_{D}$ is endogenously determined. Deposits are special in that bank depositors do not have to incur monitoring cost to prevent falling victim to cash flow diversion by banks: banks are assumed to have access to a technology that allows them to commit not to divert the part

10 To raise one unit of financing from public market investors, firms need to pledge cash flows of $\mathbb{E}\left[C F_{s}(k)\right]=1+c_{k}$. Then, $P V_{P}=1$.

11 While we assume a continuum of banks, our qualitative results only require a finite number of banks that behave competitively in the asset market. From a technical perspective, however, a finite number of banks would introduce cumbersome indivisibilities in the optimal asset allocation among banks.

12 It is without loss of generality to disallow dividend payouts at time 0. 
of their cash flow that is needed to pay their depositors.13

Assets. In contrast to public market investors bankers are endowed with a technology that allows them to monitor entrepreneurs at zero cost. Public market finance is thus not a perfect substitute for bank finance, since public markets are less efficient in monitoring issuers 14 The joint assumption on the absence of monitoring costs for bank deposits and the banks' advantage to monitor firms captures - in reduced form - the essence of Diamond (1984). Importantly, our results can be easily generalized to the more realistic situation in which banks are more efficient only for a subset of borrowers, say for small businesses. We provide further discussion in Section 5. As higher values for the parameter $c$ imply that public markets are at a bigger comparative disadvantage in monitoring borrowers, we will often also refer to $c$ as a measure of the extent to which public investors compete with banks for investments.

Like public market investors, banks have also have access to a storage technology with zero interest, which we refer to as cash. Denote the amount the bank invests in cash at date 0 by Cash $_{0}$. Then, the total book value of a bank's loan portfolio at date $0, A_{0}$, is given by

$$
A_{0}=E_{0}+D_{0}-\text { Cash }_{0}
$$

Let $x_{i} \geq 0$ denote the portfolio weight of entrepreneur $i$ in a bank's loan portfolio and let $r_{i}^{s}$ denote the associated state-contingent rate of return on loan $i$. Then, the rate of return on a bank's total investment in loans, $A_{0}$, is given by:

$$
r_{A}^{s}=\sum x_{i} r_{i}^{s}
$$

The rate of return $r_{i}^{s}$ will be endogenously determined through the equilibrium promised coupon yield $y(i)$. We note that if banks exclusively finance a borrower, then the statecontingent net return of a loan to firm $i$ satisfies:

$$
r_{i}^{s}=\min \left\{y(i), C_{s}(i)-1\right\}
$$

13 Unlike regular firms, banks have a branch or ATM network that ensures depositors' fast access to funds, allowing them to run at any point in time. A similarly fast access is available to money market mutual fund investors that can withdraw funds electronically. While we treat banks' ability to commit as an exogenous technology, existing theoretical work shows how demand deposits can endogenously act as a commitment device for banks. See, e.g., Calomiris and Kahn (1991) and Diamond and Rajan (2001).

14 Differences between relationship lending and arm's length lending are also present in Petersen and Rajan (1995), Rajan and Zingales (2001), or Bernardo and Welch (2013). 
Alternative interpretation of $c$. It is useful to highlight that the parameter $c_{k}$ does not necessarily have to represent the (differential) monitoring cost, which is our leading interpretation throughout the model presentation. An alternative interpretation of the setting is that only bank deposits are perceived as fully liquid claims by public market investors and that all other securities are associated with an illiquidity cost of $c_{k} \cdot 15$

Financial distress cost. In our model bankers have special skills in the form of a monitoring technology advantage and an ability to issue deposits that are not subject to cash flow diversion problems. These skills make bank defaults socially costly. Absent a bailout, a bank $j$ will default in state $s, N_{s}(j)=1$, if the required repayment to depositors $D_{0}\left(1+r_{D}\right)$ at time 1 exceeds its value of assets inclusive of its cash reserve, $\left(1+r_{A}^{s}\right) A_{0}+$ Cash $_{0}$. Following Leland (1994), we summarize welfare losses associated with a bank's default on depositors by stipulating that a fraction $0<\alpha \leq 1$ of assets is lost in bankruptcy. While our modeling setup only consists of one period, these bankruptcy costs are meant to incorporate not only the social loss from existing assets, but also, in reduced form, the value of the bankers' skill in future periods.

Objective. Since loan terms are determined in a market where banks and public market investors compete, each banker takes returns, $r_{i}^{s}$, as given and maximizes the market value of his inside equity share, $E_{M}^{I}$, by choosing the optimal capital structure, i.e., its equity issuance $\Delta_{E}$, and deposits $D_{0}$, to finance its loan investments $A_{0} \geq 0$ with respective weights $\left\{x_{i}\right\}$ and cash holdings Cash $_{0} \geq 0$.

$$
E_{M}^{I}=\mathbb{E}_{0}\left[\max \left\{\left(1+r_{A}^{s}\right) A_{0}+\text { Cash }_{0}-D_{0}\left(1+r_{D}\right), 0\right\}\right]-\Delta_{E}\left(1+c_{E}\right)
$$

Here, the term $\max \left\{\left(1+r_{A}^{s}\right) A_{0}+\right.$ Cash $\left._{0}-D_{0}\left(1+r_{D}\right), 0\right\}$ reflects the total market value of bank equity at time 1, i.e., the state-dependent asset payoffs from the loan portfolio and cash net off the promised repayment to debt holders, subject to limited liability. The insider's share, $E_{M}^{I}$, accounts for the market value of cash flows that needs to be pledged to outside equity holders to ensure that $P V_{P}=\Delta_{E}$, i.e., $\Delta_{E}\left(1+c_{E}\right)$ (see Eq. 2).

${ }_{15}$ Bank deposits might provide a "convenience yield" by offering depositors fast access to cash (and other services) via a branch or ATM network. The liquidity benefit of deposits is also consistent with Diamond and Dybvig (1983) and Gorton and Pennacchi (1990), who highlight the special features of deposits. 


\subsection{Regulator}

Ex-post interventions at date 1. The regulator is the only agent with relevant actions at both date 0 and 1 . At date 1, the regulator may intervene and bail out ailing banks to avoid the cost of financial distress. Importantly, we assume that the regulator cannot precommit to date 1 actions, which gives rise to a potential time-inconsistency problem akin to Kydland and Prescott (1977). In particular, if at time 1, a bank were to default in the absence of a bailout, $N_{s}(j)=1$, the government can avoid the associated bankruptcy $\operatorname{cost} \alpha A_{0}\left(1+r_{A}^{s}\right)$ by transferring funds $B_{s}(j)$ to the bank so that depositors can be repaid, i.e.,

$$
B_{s}(j)+\left(1+r_{A}^{s}\right) A_{0}+\operatorname{Cash}_{0}(j) \geq D_{0}\left(1+r_{D}\right) .
$$

However, bailouts induce proportional deadweight taxation $\operatorname{costs} \tau$.

Ex-ante regulation at date 0 . To address this commitment problem, the regulator may impose regulation in the form of minimum equity ratio requirements on bankers at date 0 .

$$
e \equiv \frac{E_{0}}{A_{0}} \geq e_{\min }
$$

This type of regulation corresponds to actual bank capital regulation under Basel III: all corporate loans obtain a standardized risk-weight of $100 \%$, whereas cash is subject to a risk-weight of $0 \%$. Restricting the regulatory toolset in such a way is not without loss of generality from a theoretical perspective, but allows us to clearly develop the intuition for the partial and general equilibrium effects of varying capital requirements. As we will discuss in Section 5, our results will qualitatively go through as long as the set of feasible conditioning signals in regulation is coarser than the information set of banks: Then, there exists a residual moral hazard problem in the asset choice of banks.

Welfare. Let $\mu_{B}(i)$ and $\mu_{P}(i)$ denote whether firm $i$ is funded by a bank $(B)$ or a public market investor $(P)$, respectively. Then, expected social welfare at time $t, W_{t}$, consists of a) the total expected surplus generated by funded firms, b) the monitoring costs incurred by public market investors, c) the expected distress cost incurred by defaulting banks and 
d) the social tax distortions induced by bailouts.

$$
\begin{aligned}
W_{t} & =\mathbb{E}_{t} \int_{0}^{1}\left(C_{s}(i)-1\right)\left(\mu_{B}(i)+\mu_{P}(i)\right) d i-c \cdot \int_{0}^{1} \mu_{P}(i) d i-c_{E} \cdot \int_{0}^{1} \Delta_{E}(j) d j \\
& -\alpha \cdot \mathbb{E}_{t} \int_{0}^{1} N_{s}(j) A_{s}(j) d j-\tau \cdot \mathbb{E}_{t} \int_{0}^{1} B_{s}(j) d j .
\end{aligned}
$$

Government regulation at time 0 and interventions at time 1 affect welfare through various channels. Capital requirements, $e_{\text {min }}$, not only affect welfare through the ex-ante funding decisions of the banking sector (and public market investors), but also limit the size of required ex-post bailouts to prevent socially cost bank failures. Ex-post bailouts, $B_{s}(j)$, directly enter welfare in period 1 due to the associated tax distortions.

We summarize the timing of actions by the various players as follows.

\section{Timing of events.}

1. Date 0

(a) The regulator sets minimum bank capital ratio requirements $e_{\min }$.

(b) Each bank raises outside equity, $\Delta_{E}$.

(c) Banks raise deposits $D_{0}$ from public market investors.

(d) Firms raise financing from public market investors and banks.

(e) Firms that obtain financing invest in their projects.

2. Date 1

(a) Nature determines the aggregate state $s$.

(b) Project and loan payoffs are realized.

(c) The regulator observes a bank's shortfall and decides on bailouts, $B_{s}(j)$.

(d) Bankruptcy and bailout costs are realized. 


\section{Analysis}

\subsection{Equilibrium}

Given the just described sequence of actions, we use subgame perfection as our equilibrium concept. We note that most of our analysis focuses on the subgame in which the regulator has chosen a certain level $e_{\min }$. Before providing a definition of the equilibrium, it is useful to simplify banks' decision problem (see Eq. 7). A bank would never have a strict preference to hoard cash at 0 return. We thus restrict our analysis to the case where gross debt equals net debt, i.e., $D_{0}=A_{0}(1-e)$. This allows us to restate the bank decision problem in terms of 3 choice variables: equity issuance $\Delta_{E}$, leverage $e$, and portfolio weights $\left\{x_{i}\right\}$.

\section{Definition 1 Subgame perfect equilibrium}

a) The regulator maximizes expected welfare $W_{t}$ at each point in time $t$, by choosing minimum equity capital requirements $e \geq e_{\min }$ at time 0 and bailouts $B$ at time 1.

b) Each firm $i$ maximizes its expected value of profits by obtaining the cheapest source of financing that results in raising 1 unit of capital.

c) Each bank $j$ maximizes the market value of inside equity, $E_{M}^{I}$, by choosing $\Delta_{E}$, its equity ratio $e \geq e_{\min }$, and its loan portfolio $\left\{x_{i}\right\} \geq 0$.

d) Public market investors invest in firm projects if and only if they expect to break-even.

In the following, we solve for equilibrium outcomes by backward induction.

Date 1 Bailouts. At time 1, investments by banks and public market investors are already made, so the regulator is the only party that moves. Since our analysis is motivated by studying the distortions resulting from implicit subsidies to insured financial institutions, we will maintain the assumption that bankruptcy costs $\alpha$ are sufficiently large relative to the tax distortions induced by bailouts, so that a bailout is always welfare-enhancing 
ex post 16 Assumption 1 provides a sufficient condition (see Lemma 5 in Appendix for formal derivation).

Assumption $1 \alpha \geq \frac{1-\underline{C}}{\underline{\underline{C}}} \tau$ where $\underline{C}=\min _{i, s} C_{s}(i)$.

Consistent with this assumption, empirical evidence by James (1991) finds quantitatively large bankruptcy costs for banks: His estimate for $\alpha$ is 30\%. Due to the resulting insurance of deposits, depositors are willing to provide funds to banks at zero interest, independent of banks' asset choices 17

$$
r_{D}=0
$$

\subsection{Date 0 equilibrium actions}

\subsubsection{Firm funding stage}

We will now analyze which firms are funded, and whether they obtain funding from banks or from public market investors. We determine how regulated banks make funding decisions given that they face competition from public markets, which provide firms with an outside option of $\max \{N P V(i)-c, 0\}$. In a first step, this requires us to analyze how banks value a marginal asset and how they choose optimal portfolios.

Using $r_{D}=0$, we may simplify the banker's objective function (7) to

$$
E_{M}^{I}=\max _{\Delta_{E}, e,\left\{x_{i}\right\}} E_{0} \mathbb{E}_{0}\left[1+r_{E}^{s}\right]-\left(1+c_{E}\right) \Delta_{E}
$$

${ }^{16}$ While in our model government bail-outs avoid bank-specific financial distress cost, it seems widely accepted that in practice government bailouts of large, insolvent financial institutions are also undertaken to avoid triggering a cascade of defaults by those institutions' counterparties, their counterparties, etc., that could result in a system-wide financial crisis and recession. Modeling such a process additionally is possible, but would clutter the model considerably without adding relevant additional insights regarding the ex-ante choice of bank capital requirements.

${ }^{17}$ Even absent a bailout guarantee, an asset substitution problem may arise after a bank has issued debt. However, without a bailout guarantee, incentives for risk shifting would be reduced since debt holders would require higher yields from banks that take risks (in particular, in the presence of covenants that address banks' asset choice), or not even invest. We also note that all of our results are robust to probabilistic rather than certain bailouts - probabilistic bailouts would be reflected in the repayment terms demanded by rational bank debt holders, so that $r_{D}>0$, but would generally still distort banks' ex ante risk-taking incentives. 
where the state-contingent return on total bank equity capital, $r_{E}^{s}$, satisfies:

$$
r_{E}^{s} \equiv \max \left\{\frac{\sum x_{i} r_{i}^{s}}{e},-1\right\}
$$

We note that due to the competitive environment, an individual bank takes equilibrium loan returns $r_{i}$ as exogenously given. Also observe that an individual bank's loan portfolio problem $\left\{x_{i}\right\}$ is independent of bank capital $E_{0}$, but it interacts with the equity ratio $e$. It is therefore instructive to first solve for the deposit/loan funding equilibrium conditional on some exogenous level of bank book equity $E_{0}=\bar{E}_{0}+\Delta_{E}$. In Section 3.2.2, we will determine the equilibrium amount of bank capital raised from public markets, $\Delta_{E}$.

Marginal asset valuations and defaults. Despite risk-neutrality, banks' marginal asset valuations depend on their overall portfolio strategy $x$ and the equilibrium return characteristics (prices) of all other assets in their bank's portfolio. In particular, it matters whether bank equity holders are wiped out in a state of the world $s$ or not. We will refer to this outcome as a bank default, although default will be avoided in equilibrium via government bailouts. A bank defaults in some state $s$ if and only if the loss on the overall loan portfolio is greater than the bank's equity buffer, that is, $r_{A}^{s}=\sum x_{i} r_{i}^{s}<-e$. Let $\Sigma_{B}(x)$ denote the set of states where a bank with portfolio strategy $x$ defaults

$$
\Sigma_{B}(x)=\left\{s \in S: \sum x_{i} r_{i}^{s}<-e\right\}
$$

so that $\Sigma_{B}^{\complement}(x)=S \backslash \Sigma_{B}(x)$ is the set of survival states.

Lemma 1 Given loan returns $r_{i}^{s}$, a bank with equity ratio e and portfolio $x$, marginally values a payoff of $C F^{s}$ as

$$
P V_{B}(i \mid x)=\frac{\mathbb{E}\left[C F^{s}(i) \mid \Sigma_{B}^{\complement}(x)\right]}{1+\mathbb{E}\left[r_{A}^{s} \mid \Sigma_{B}^{\complement}(x)\right]}
$$

\section{Proof: See Appendix.}

This lemma illustrates an important ingredient for the remaining analysis of the paper. At the margin, banks value payoffs only in the states of the world in which they do not default, $\Sigma_{B}^{\complement}(x)$. An additional payoff generated in default states, $\Sigma_{B}(x)$, simply reduces the required ex-post bailout by taxpayers to pay bond holders, but does not affect the equity value. 
Clearly, by definition of a bank default and individual loan return realizations $r_{i}^{s}$ (see Eq. 6) a portfolio of a bank that defaults in states $\Sigma_{B}(x)$ must include sufficiently many borrowers with low project payoffs in those states, i.e., satisfying $r_{i}^{s}<-e$ or equivalently $C_{s}(i)<1-e$. For each borrower $i$, it is therefore useful to define the corresponding set of states in which the borrower may contribute to a bank default:

$$
\Sigma(i, e)=\left\{s \in S: C_{s}(i)<1-e\right\}
$$

Competitive loan market. We will now analyze the implications of Lemma 1 when banks interact with other optimizing banks and public market investors in a competitive market for firm loans, and, in particular, derive the distribution of $e$ and $x$ and loan terms $r_{i}^{s}$ for the entire banking sector given $E_{0}$.

Even though banks may differ in equilibrium in terms of their leverage and portfolio choices, all equilibrium strategies must be equally profitable. Banks are ex ante identical and would otherwise have access to a profitable deviation. This equilibrium restriction implies

Lemma 2 All banks share the same equilibrium expected return on equity

$$
\mathbb{E}\left[r_{E}^{s}(j)\right]=\bar{r}_{E} \geq 0
$$

\section{Proof: Omitted.}

Combining Lemma 2 and marginal valuations of an individual bank (Lemma 1), we obtain

Proposition 1 Properties of optimal bank loan portfolios and bank capital structure:

If a borrower $i$ has a positive weight in the loan portfolio of bank $j$, then

1) all remaining borrowers $i^{\prime}$ in the loan portfolio of bank $j$ satisfy $\Sigma\left(i^{\prime}, e\right)=\Sigma(i, e)$.

2) bank $j$ chooses $e=e_{\min }$ if $\Sigma\left(i, e_{\min }\right)$ is non-empty or $\bar{r}_{E}>0$.

3) bank $j$ defaults in states $\Sigma_{B}(j)=\Sigma\left(i, e_{\min }\right)$.

Proof: See Appendix.

This Proposition highlights key properties of individually optimal portfolios in a competitive market taking as given the equilibrium returns $r_{i}^{s}$. First, the fact that the bank 
deposit rate doesn't reflect a bank's asset risk $\left(r_{D}=0\right)$, only becomes valuable if a bank's overall asset position would have caused a bank default in the absence of the bailout guarantee, i.e., when $\Sigma_{B}(j)$ is non-empty. Then, ex-post bailouts create an ex-ante financing subsidy, since rational debt holders would have demanded a higher deposit rate in the absence of bailouts. The (marginal) value of a financing subsidy for a particular borrower $i$ is maximal for a bank that levers up to the regulatory constraint, $e=e_{\min }$, and defaults precisely in the states in which the borrower marginally contributes to a bank default, $\Sigma_{B}(j)=\Sigma\left(i, e_{\min }\right)$. The present value of the financing subsidy for borrower $i$ under optimum bank financing, denoted as $\sigma\left(i, e_{\min }\right)$, equals the (marginal contribution to the) expected government transfer to debt holders, the government put.

$$
\sigma\left(i, e_{\min }\right)=\sum_{s \in S} p_{s} \max \left\{1-e_{\min }-C_{s}(i), 0\right\}=\sum_{s \in \Sigma\left(i, e_{\min }\right)} p_{s}\left(1-e_{\min }-C_{s}(i)\right)
$$

The value of the subsidy equals the expected shortfall of firm cash flows, $C_{s}(i)$, to repay the fraction of the project financed by depositors, $1-e_{\min }$. The lower the equity ratio requirement, $e_{\min }$, the larger the value of the subsidy. We note that this is (another) reason for why the Modigliani-Miller theorem is violated, as the amount of debt financing affects the total amount of payments to all security holders.

Discussion: Endogenous segmentation of banking sector. The banking sector as a whole can only reap the full value of the financing subsidy for each borrower, see (17), if the banking sector is segmented along portfolio strategies yielding the same expected return. Competition between banks ensures that this specialization occurs in equilibrium. For example, a bank $j$ with overall asset portfolio payoffs sufficient to repay debt holders in all states, $\Sigma_{B}(j)=\emptyset$, would not be able to extract a financing subsidy by adding some firm $i$ with $\sigma\left(i, e_{\min }\right)>0$ to the portfolio on the margin, and thus could not compete on loan terms with an optimizing bank featuring $\Sigma_{B}=\Sigma\left(i, e_{\min }\right)$. Conversely, a bank that defaults in some states of the world, $\Sigma_{B}(j) \neq \emptyset$, would not value all the cash flows produced by a safe borrower delivering $y$ in all states of the world (see Lemma 1). Hence, it could not compete with another bank $j^{\prime}$ that never defaults, $\Sigma_{B}\left(j^{\prime}\right)=\emptyset$.

We note that such bank specialization in loan portfolios is a very stark theoretical prediction, clearly laying out the incentives on how to optimally exploit bailout guarantees within the banking sector. Of course, given that we think of the states as aggregate states, we expect borrowers to produce low cash flows $C_{s}<1-e_{\min }$ in similar states of the world, partially limiting the degree of observable heterogeneity across banks' loan portfolios. Still, 
recent empirical evidence by Rappoport, Paravisini, and Schnabl (2014) is very much consistent with such predicted endogenous bank specialization in loan portfolios.

Funding decisions of banking sector. Going forward, we will mainly be interested in the aggregate behavior of the banking sector given efficient bank specialization. Then, the total private surplus generated by the relationship between a borrower $i$ and the banking sector, denoted as $\Pi\left(i, e_{\min }\right)$, can be decomposed into a) the additional social surplus above and beyond the surplus generated by public market financing, $\min \{c, N P V(i)\}$, and b) the "artificial" surplus induced by the financing subsidy $\sigma\left(i, e_{\min }\right)$. Clearly, since non-funding of an issuer is always an option, $\Pi\left(i, e_{\min }\right)$ is bounded below by zero.

$$
\Pi\left(i, e_{\min }\right)=\max \left\{\min \{c, N P V(i)\}+\sum_{s \in \Sigma\left(i, e_{\min }\right)} p_{s}\left(1-e_{\min }-C_{s}(i)\right), 0\right\}
$$

It is evident that public market investors can only compete along the social surplus dimension, $N P V(i)$. Higher competition, i.e., lower $c$, caps the private surplus from a relationship between banks and sufficiently value-creating borrowers, $N P V(i)>c$, who can bypass the banking system and obtain financing from public market investors 18 In contrast, it does not affect the private surplus for firms without this outside option, in particular for firms with negative NPV that would not be worth financing without subsidized financing. Since uninsured public market investors do not obtain financing subsidies, they are thus at a comparative disadvantage for projects exhibiting down side risk, i.e., with payoffs $C_{s}(i)<1-e_{\min }$ for some states of the world. As a result, the private surplus from funding highly risky and negative NPV projects might be greater than the private surplus generated by positive NPV projects without downside risk. As is evident from (18), such perverse incentives are particularly prominent if competition is high ( $c$ is low) and equity ratio requirements, $e_{\min }$, are low.

Lemma 3 Banking sector ranking: If borrower $i$ is financed by banks, then any borrower $i^{\prime}$ generating private surplus $\Pi\left(i^{\prime}, e_{\min }\right)>\Pi\left(i, e_{\min }\right)$ is financed by banks as well.

Proof: Follows from profit maximization of banks.

${ }^{18}$ Our setup can easily handle security-or borrower specific comparative advantage $c(i)$. The first term in Equation 18 becomes: $\min \{c(i), N P V(i)\}$. 
Since banks might be indifferent among firms producing the same private surplus, but different social surplus, we make

Assumption 2 Among borrowers with identical $\Pi\left(i, e_{\min }\right)$, banks first choose to fund the borrowers with the highest social surplus $N P V(i)$. Banks do not fund firms with $\Pi\left(i, e_{\min }\right)=0$ if $N P V(i)<0$.

Whether the private surplus $\Pi\left(i, e_{\min }\right)$ is realized in equilibrium and if so, how it is split up, depends on the relation between the aggregate funding capacity of the banking sector, denoted as $A_{\max }$, and the supply of firms with positive private surplus, i.e., $\int_{i: \Pi\left(i, e_{\min }\right)>0} d i$. Given $E_{0}$ and $e_{\min }$, the funding capacity of the banking sector, $A_{\max }$, satisfies

$$
A_{\max }\left(e_{\min }\right)=\frac{E_{0}}{e_{\min }}
$$

If the banking sector can finance all privately profitable projects, $A_{\max } \geq \int_{i: \Pi\left(i, e_{\min }\right)>0} d i$, competition between banks for firm projects ensures that funded firms can extract the entire private surplus $\Pi\left(i, e_{\min }\right)$. Thus, firms reap the social surplus of their project $N P V(i)$ as well as the financing subsidy $\sigma\left(i, e_{\min }\right)$, which competitive banks pass on to borrowers. The marginal investment of the banking sector is cash which produces private (and social) surplus of zero. As a result, the equilibrium rate of return on equity for the banking sector satisfies $\bar{r}_{E}=0$.

In contrast, if the banking sector is capacity constrained, $A_{\max }<\int_{i: \Pi\left(i, e_{\min }\right)>0} d i$, profit maximization implies that the banking sector rationally drops the funding of projects with the lowest private surplus, according to the ranking in Lemma 3. Banks can now extract the entire private surplus on the marginal funded firm, denoted as project $i_{M}$, since all firms with $\Pi\left(i, e_{\min }\right) \leq \Pi\left(i_{M}, e_{\min }\right)$ pledge the entire private surplus $\Pi$ to attract scarce bank capital. The levered rate of return on equity for the banking sector then satisfies $\bar{r}_{E}=\frac{\Pi\left(i_{M}, e_{\min }\right)}{e_{\min }}$. The financing terms on all loans provided by the banking sector to firms with $\Pi\left(i, e_{\min }\right)>\Pi\left(i_{M}, e_{\min }\right)$ are set such that the expected rate of return on equity is $\bar{r}_{E}$. Firms that are funded by banks thus extract $N P V(i)+\sigma\left(i, e_{\min }\right)-\Pi\left(i_{M}, e_{\min }\right)$. Among the unfunded projects by the banking sector, public market investors fund all firms with surplus $N P V(i) \geq c{ }^{19}$ We summarize these insights in the following Proposition.

$\overline{{ }^{19}}$ As a result, regardless of $e_{\min }$ and $E_{0}$, all firms with sufficiently high social surplus, $N P V(i) \geq c$, are always funded. 
Proposition 2 Competitive loan equilibrium given $E_{0}$ and $e_{\min }$ :

1) If banks can finance all privately profitable projects, $A_{\max } \geq \int_{i: \Pi\left(i, e_{\min }\right)>0} d i$, banks' marginal investment is cash. As a result, $\bar{r}_{E}\left(e_{\min }, E_{0}\right)=0$.

2) If banks cannot finance all privately profitable projects, define the marginal firm funded by banks, $i_{M}$, as the solution to $A_{\max }\left(e_{\min }\right)=\int_{i: \Pi\left(i, e_{\min }\right) \geq \Pi\left(i_{M}, e_{\min }\right)} d i$.

a) The rate of return on bank equity satisfies $\bar{r}_{E}\left(e_{\min }, E_{0}\right)=\Pi\left(i_{M}, e_{\min }\right) / e_{\min }$.

b) Banks fund all firms with $\Pi\left(i, e_{\min }\right)>\Pi\left(i_{M}, e_{\min }\right)$, and use the remaining capacity to fund projects with $\Pi\left(i, e_{\min }\right)=\Pi\left(i_{M}, e_{\min }\right)$.

c) Of the remaining firms, public markets fund all firms $i$ with $N P V(i) \geq c$.

For each firm $i$ financed by banks, the equilibrium yield, $y(i)$, satisfies

$$
\sum_{s \in S} p_{s} \max \left\{\frac{\min \left\{y(i), C_{s}(i)-1\right\}}{e_{\min }},-1\right\}=\bar{r}_{E}
$$

This Proposition completely describes the funding of firm projects and the division of surplus given $e_{\min }$ and $E_{0}$. In particular, it derives the equilibrium loan yields, $y(i)$, and state-contingent returns, $r_{i}^{s}=\min \left\{y(i), C_{s}-1\right\}$, for all firms funded by banks.

\subsubsection{Raising bank capital}

The analysis so far took place conditional on an existing amount of equity issuance leading to $E_{0}=\bar{E}_{0}+\Delta_{E}$. We now consider the incentives of banks to raise additional equity. Since each bank is infinitesimal, it takes the equilibrium rate of return on equity of the entire banking sector as exogenously given. Formally, let $\bar{E}_{0}(j)$ and $\Delta_{E}(j)$ denote bank $j$ 's initial wealth and equity issuance, respectively so that the aggregate initial wealth and issuances satisfy $\bar{E}_{0}=\int_{0}^{1} \bar{E}_{0}(j) d j$ and $\Delta_{E}=\int_{0}^{1} \Delta_{E}(j) d j$. Then, the (relevant) decision problem of an individual bank $j$ is

$$
\max _{\Delta_{E}(j)} \Delta_{E}(j)\left[\bar{r}_{E}\left(e_{\min }, \bar{E}_{0}+\Delta_{E}\right)-c_{E}\right]
$$

Intuitively, an individual bank $j$ only has an incentive to raise equity as long as the expected return on equity associated with a marginal investment exceeds the marginal 
cost of issuing equity. Since $\bar{r}_{E}\left(e_{\min }, \bar{E}_{0}+\Delta_{E}\right)$ is a decreasing function of $\Delta_{E}$ no firm would have an incentive to raise additional equity if $\bar{r}_{E}\left(e_{\min }, \bar{E}_{0}\right)<c_{E}$. If, on the other hand, $\bar{r}_{E}\left(e_{\min }, \bar{E}_{0}\right)>c_{E}$, each individual firm has a strict incentive to raise equity. In this case, a competitive equilibrium must be characterized by $\bar{r}_{E}\left(e_{\min }, \bar{E}_{0}+\Delta_{E}\right)=c_{E}$ so that competitive banks don't make additional profits on equity issuances. Then, banks issue equity until all firms with $\frac{\Pi\left(i, e_{\min }\right)}{e_{\min }} \geq c_{E}$ are funded.

Proposition 3 Raising bank capital

1) If $\bar{r}_{E}\left(e_{\min }, \bar{E}_{0}\right)<c_{E}$, no bank raises equity. Proposition 2 applies with $E_{0}=\bar{E}_{0}$.

2) If $\bar{r}_{E}\left(e_{\min }, \bar{E}_{0}\right) \geq c_{E}$, the average bank raise equity $\Delta_{E}$ until all firms with $\frac{\Pi\left(i, e_{\min }\right)}{e_{\min }} \geq c_{E}$ can be funded. Loan terms for all borrowers are set such that $\bar{r}_{E}\left(e_{\min }, \bar{E}_{0}+\Delta_{E}\right)=c_{E}$.

\section{Proof: Omitted.}

This Proposition completes the characterization of how a competitive financial sector responds to equity ratio requirements. In particular, we have determined the capital structure of banks, $\Delta_{E}$ and $e$, as well as the lending decisions of the banking sector given $e_{\text {min }}$. We now study the comparative statics in $e_{\text {min }}$, which will also determine the optimum level of capital ratio requirements as a by-product.

\subsubsection{Capital ratio requirements}

Economy without capital requirements. We first characterize an unregulated economy to highlight the need for regulation. Formally, this corresponds to the equilibrium of the subgame (see Definition 1) in which the regulator is constrained to choose $e_{\min }=0$.

Proposition 4 In an economy without equity ratio requirements:

1) An issuer $i$ is funded by banks, $\mu_{B}(i)=1$, if $C_{s}(i)>1$ for some state $s$.

2) All funded firms can obtain financing at a yield of $y(i)=0$.

3) Ex-ante welfare is given by

$$
W_{0}=\int_{i: \Pi(i, 0)>0}[N P V(i)-\tau(\sigma(i, 0))] d i .
$$

Proof: See main text.

The intuition for these results is simple. First, as long as a firm project offers a positive asset return in one state of the world $s, C_{s}>1$, it generates private surplus $\Pi(i, 0)>0$, 
since banks with an equity ratio of $e=0$ (in the limit) can capture the upside in one state of the world whereas tax payers subsidize debtholders on the downside. Due to the absence of leverage restrictions, the funding capacity of the banking sector, $A_{\max }$, exceeds the supply of projects with positive private surplus, so that all these firms obtain financing. Case 1 of Proposition 2 applies. Loan yields for funded firms are completely uninformative about default risk, $y=0$, since the marginal buyer, the banking sector, does not price default risk due to the financing subsidies (see 20). At these distorted prices, public market investors cannot compete with banks and play no role in this economy.

To analyze welfare distortions of the unregulated equilibrium (see Proposition 4), it is useful to define the first-best outcome $W_{0}^{*}$ which is

$$
W_{0}^{*}=\int_{i: N P V(i) \geq 0} N P V(i) d i .
$$

First-best welfare is achieved if banks exclusively fund all surplus-generating projects in the economy and none of the banks default, so that no bailouts are necessary. The degree of welfare distortions in the unregulated economy relative to first-best depends on a) the degree of ex-ante overinvestment, i.e., how many surplus destroying projects are funded and $\mathrm{b}$ ) the expected taxation costs of bailouts to rescue failing banks, $\tau \int_{\Pi(i, 0)>0} \sigma(i, 0) d i$.

Both the ex-ante incentives to invest in social surplus reducing projects as well as the ex-post bailouts cost vary with the cross-sectional distribution of $\sigma(i, 0)$ in the economy. If, hypothetically all projects in the economy were safe, positive NPV projects, so that $\sigma(i, 0)=0 \forall i$, the unregulated economy achieves the first-best outcome $W_{0}^{*}$. On the other hand, if the economy features a lot of negative NPV investments with high upside payoffs, then the unregulated economy will be subject to distortions and equity capital ratio requirements may lead to welfare improvements.

Comparative statics of capital requirements. Introducing capital requirements implies a trade-off. On the benefit side, an increase in $e_{\min }$ lowers the implicit financing subsidy for each project (see 17) and thus aligns the incentives of each individual bank and the banking sector, reflected in $\Pi\left(i, e_{\min }\right)$, better with the social ranking of projects, $N P V(i)$. In addition, the higher equity buffer lowers the required ex-post bailouts and hence the associated taxation distortions. In line with conventional wisdom, more "skinin-the game" has a positive incentive effect on an individual bank, the microprudential effect of increasing capital requirements. 
These benefits have to be weighed against the potential cost of constraining the aggregate capacity of the banking sector, $A_{\max }$, to fund all projects with positive private NPV, akin to a cap on aggregate lending. This macroprudential effect of capital requirements has an ambiguous effect on welfare. It will reduce the aggregate surplus produced by funded firms (and hence welfare) if the marginal funded project, $i_{M}$, generates positive NPV. In this case, the marginal project will either get (inefficiently) funded by public market investors (if $N P V \geq c$ ) or may not be financed at all. We summarize these insights in

Proposition 5 Comparative statics of $e_{\min }$. For a given level of $e_{\min }$,

1) If banks can finance all privately profitable projects, a marginal increase in capital requirements is welfare enhancing.

2) If the banking sector's capacity is not sufficient to finance all privately profitable projects, the welfare effect of a marginal change in $e_{\min }$ is ambiguous. An increase in capital requirements will reduce social surplus produced by firms if and only if the marginal firm, $i_{M}$, has positive $N P V$.

For the further analysis it is useful to define a threshold level for $e_{\min }$ with sufficient "skin-in-the-game."

Definition 2 Let $\hat{e}$ denote the lowest level of $e_{\min }$ such that for all $e_{\min } \geq \hat{e}$, all projects with negative NPV do not generate private surplus.

Clearly, such a threshold level always exists since $\Pi(i, 1)=\min \{c, N P V(i)\}$. We obtain

Lemma 4 Sufficient conditions for attaining first-best welfare with capital requirements

1) If for some $e^{*}>\hat{e}, \bar{E}_{0} \geq e^{*} \int_{i: N P V(i)>0} d i$ and $\sigma\left(i, e^{*}\right)=0 \forall i$, then set $e_{\min }=e^{*}$.

2) If $c_{E}=0$ or $c=0$, then set $e_{\min }=1$.

Proof: We first prove part 1) Since at $e^{*} \geq \hat{e}$ all projects with positive private surplus also generate social surplus, we just need to ensure that the funding capacity given $\bar{E}_{0}$, i.e., $\bar{E}_{0} / e^{*}$, exceeds the supply of positive NPV projects. The first case of the respective Propositions 2 and 3 applies. Moreover, financing subsidies need to be zero for all projects (which always holds if $e_{\min }=1$ ). For part 2), see main text.

These conditions are rather intuitive. If the initial level of bank equity, $\bar{E}_{0}$, is sufficiently high capital requirements can eliminate asset substitution incentives without constraining 
investment in assets with positive NPV. The condition $c_{E}=0$ is in similar spirit. Here, the initial level of bank equity is irrelevant since bankers can always raise equity at zero social cost, so the regulator just needs to target individual bank incentives and can disregard macroprudential effects. Finally, if $c=0$, banks have no social benefit relative to public market investors. Optimal regulation can ensure first-best welfare by requiring banks to back all their deposits with liquid assets, i.e., cash. Investments in real assets have to be fully backed by equity, $e_{\min }=1$. If the latter two conditions apply, capital requirements imply no trade-off, which is the essence of the argument by Admati, DeMarzo, Hellwig, and Pfleiderer (2011).

\section{A Two-type Economy}

In the previous section we characterized equilibrium properties of the model, allowing for general cross-sectional project payoff distributions and arbitrary (but finite) number of states. In this section, we illustrate our model's predictions based on a simple, stylized economy with two project types to illustrate the basic mechanisms. We will focus on the comparative statics of capital requirements, and, in particular, demonstrate the ambiguous effect on welfare when the aggregate funding capacity of the banking sector is constrained (see Case 2) of Proposition 5).

There are two states $s \in\{L, H\}$ and projects can be of two types $i \in\{g, b\}$. With some abuse of notation, we now use $i$ to index types rather than individual firms. Good types $(i=g)$ generate a safe payoff of $R>1+c$ in both aggregate states of the world ( $H$ and $L$ ). In contrast, bad types $(i=b)$ generate a payoff of $R$ only in the $H$-state and zero otherwise. Bad projects are further assumed to be surplus-destroying from a social perspective, that is, $p_{H} R<1$. Let $\pi_{g}$ denote the mass of issuers with a good project and $\pi_{b}=1-\pi_{g}$ the mass of issuers with a bad project.

To increase the transparency of the exposition, we will first analyze equilibrium outcomes under the premise that banks have a given, fixed amount of equity, $\bar{E}_{0}$ (or equivalently, prohibitively high equity issuance $\operatorname{costs} c_{E}$ ). In a second step, we then analyze banks' optimal equity issuance choices. 


\subsection{Fixed Bank Equity}

For the discussion it is useful to keep track of two types of thresholds for equity-ratio requirements $e_{\min }$ that play a key role in the characterization of equilibrium outcomes.

Capacity thresholds. The first type of threshold is related to funding capacity constraints: conditional on a fixed amount of equity $\bar{E}_{0}$ and a capital ratio requirement $e_{\min }$ the banking sector's maximum funding capacity is given by $A_{\max }=\frac{\bar{E}_{0}}{e_{\min }}$. Absent equity issuances, increases in ratio-requirements $e_{\min }$ scale down the funding capacity of the banking sector, and thus can impose funding capacity constraints. Correspondingly, there are threshold values for $e_{\min }$ at which the banking sector has not enough capacity to fund (1) all projects in the economy $\left(e_{\min }>\bar{E}_{0}\right),(2)$ all good projects $\left(e_{\min }>\frac{\bar{E}_{0}}{\pi_{g}}\right)$, and $(3)$ all bad projects $\left(e_{\min }>\frac{\bar{E}_{0}}{\pi_{b}}\right)$.

Ranking thresholds. The second type of threshold is related to the banking sector's private ranking of investment opportunities (see Lemma 3). This ranking determines which project types (good or bad) are dropped or added at the margin when funding capacity constraints become more or less binding. An increase in capital ratio requirements $e_{\min }$ can be effective in altering this ranking, as greater skin-in-the-game reduces the value of the financing subsidy, which only applies to bad projects. As a result, there can be two ranking thresholds in this two-type economy: first, there may exist a value for $e_{\min }$ at which the ranking switches so that good rather than bad issuers' bonds become most highly ranked by banks. Let $\tilde{e} \equiv e_{\min }: \Pi\left(g, e_{\min }\right)=\Pi\left(b, e_{\min }\right)$ denote this threshold. At the second threshold, $\hat{e}$ (see Definition 2) bad projects start to become even less profitable than cash investments and are thus dropped completely.

The following illustrations can be best understood by referring to these capacity and ranking thresholds. When capital ratio requirements $e_{\min }$ are increased, funding capacity

$A_{\max }$ is always monotonically reduced, as $A_{\max }=\frac{\bar{E}_{0}}{e_{\min }}$. Investments in a given issuer-type may, however, be insensitive to changes in $e_{\min }$ unless a capacity or ranking threshold is passed. When $e_{\min }$ passes a ranking threshold and banks are capacity constrained, the composition of funded projects changes discontinuously, as banks' ranking of investments changes. 
No competition from public markets. The first parameterization, illustrated in Figure 1, highlights the case where banks do not face competition from public markets since public markets' monitoring cost $c$ are prohibitively high (that is, $c>R-1$ ). The private surplus for both project types thus satisfies:

$$
\begin{aligned}
& \Pi\left(g, e_{\min }\right)=N P V_{g}=R-1 \\
& \Pi\left(b, e_{\min }\right)=\max \left\{N P V_{b}+p_{L}\left(1-e_{\min }\right), 0\right\}
\end{aligned}
$$

As the Private Surplus panel of Figure1 reveals, banks rank good projects always higher than bad projects, independent of the capital ratio requirement $e_{\min }$, i.e., $\Pi\left(g, e_{\min }\right)>$ $\Pi\left(b, e_{\min }\right) \forall e_{\min } \in[0,1]$. As a result, the parameterization only features the ranking threshold, $\hat{e}$ satisfying $N P V_{b}=-p_{L}(1-\hat{e})$. For $e_{\min }>\hat{e}$, the financing subsidy $\sigma\left(b, e_{\min }\right)$ is too small to make financing bad projects privately worthwhile. Banks rank bad issuers below cash investments and thus drop them completely.

Figure 1 further illustrates two capacity thresholds: first, at $e_{\min }=\bar{E}_{0}$, the banking sector's maximum funding capacity $A_{\max }$ starts to become insufficient to finance all projects in the economy - thus, projects have to be dropped in response to increases in $e_{\text {min }}$ beyond this capacity threshold. Banks drop bad projects first, as they are ranked below good projects. Second, at $e_{\min }=\frac{\bar{E}_{0}}{\pi_{g}}$, the banking sector's capacity becomes insufficient to fund all good projects in the economy. At this point, increases in $e_{\min }$ reduce banks' investment in good projects.

The Private Surplus panel further illustrates whether banks or firms extract the private surplus as a function of $e_{\min }$. For $e_{\min }<\bar{E}_{0}$, the banking sector has excess capacity such that cash is the marginal investment (Case 1 of Proposition 2). Yields on good and bad issuers' loans (see lower right panel) adjust so that banks make an expected return on equity equal to zero. For $\hat{e}>e_{\min }>\bar{E}_{0}$ banks are capacity constrained and bad projects are marginal, $i_{M}=b$, so that banks can fully extract the private surplus produced by bad issuers (Case 2 of Proposition 2). For $\frac{\bar{E}_{0}}{\pi_{g}}>e_{\min }>\hat{e}$ bad projects are non-viable (ranked below cash) and the banking sector has more capacity than needed to fund all good issuers. Thus, cash is again the marginal investment and banks make zero profits. Finally, once $e_{\min }$ reaches the capacity threshold $\frac{\bar{E}_{0}}{\pi_{g}}$ banks have insufficient capacity to fund all good projects. Good projects become marginal, $i_{M}=g$, implying that banks can extract the entire surplus from good projects.

Finally, since the initial level of bank equity high enough, $\bar{E}_{0}>\pi_{g}$, (and since $\sigma(g, \hat{e})=$ 
Private Surplus

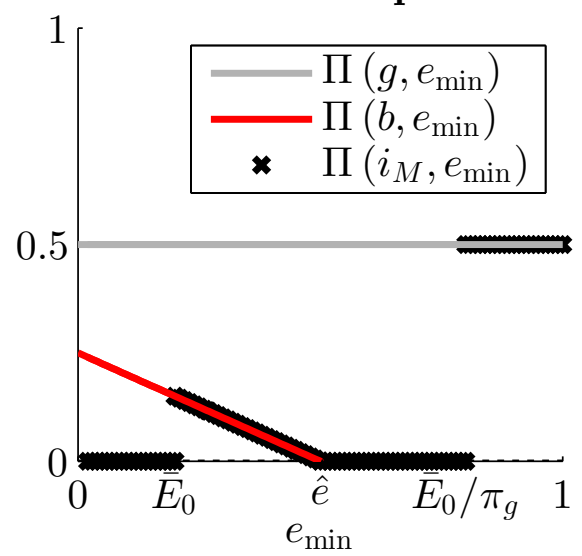

Funding Decisions

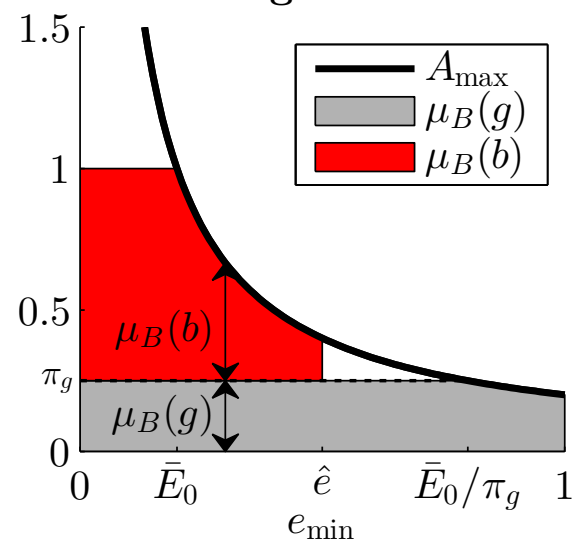

Welfare

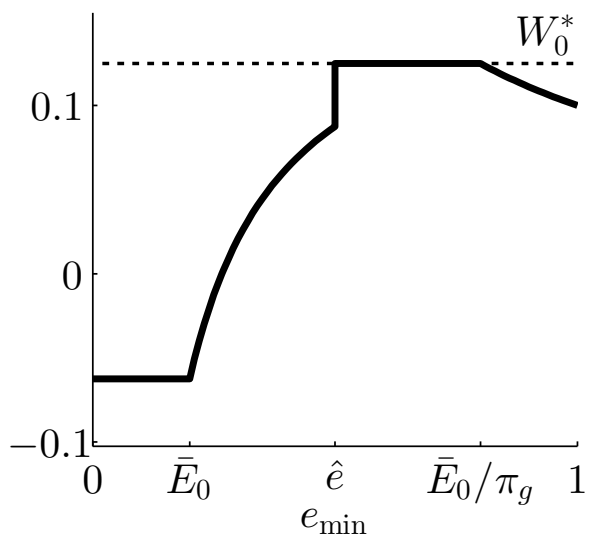

Loan Yields

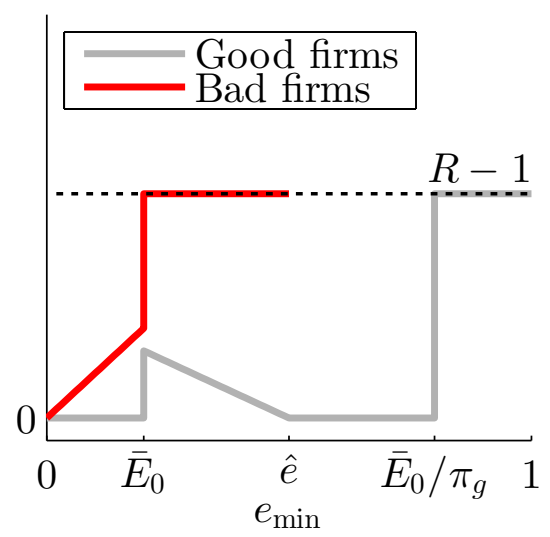

Figure 1. The figures illustrate the effect of varying equity ratio requirements, $e_{\min }$, on private surplus $\Pi$ from firm projects (upper left panel), the funding capacity $A_{\max }$ (lower left panel), welfare $W_{0}$ (upper right panel) and the loan yields for firm types, i.e., $y(i)$, (lower right panel). The term $\mu_{B}(i)$ refers to the mass of financing of firm type $i$ by banks. The parameters of the economy are chosen as follows: $p_{H}=0.5$, $R=1.5, c=0.7, \pi_{g}=0.25, \tau=0$ and $\bar{E}_{0}=0.2$. In this case, $\bar{E}_{0}=0.2<\hat{e}=0.5<\frac{\bar{E}_{0}}{\pi_{g}}=0.8$.

0) the first condition of Lemma 4 applies. As a result, optimal capital requirements of $e_{\min } \in\left[\hat{e}, \frac{E_{0}}{\pi_{g}}\right]$ can achieve the first-best outcome (see upper right panel). Capital ratio requirements can be effective in reducing investment distortions through two channels: by affecting aggregate funding capacity and rankings. The negative effect on funding capacity is beneficial at the margin when bad projects are funded by banks and reductions in capacity constrain bad investment. Capital ratio requirements can further be effective in preventing inefficient bank investment via their corrective impact on rankings (for $e_{\min } \geq$ $\hat{e})$. 
Competition from public markets. Next, in Figure 2, we adjust the original parameterization from Figure 1 to consider the case where public markets pose a competitive threat to banks. For $c<R-1$, public market investors compete with banks for good issuers and thus affect banks' profits from funding these types of borrowers. Informed public market investors, however, never compete with banks for bad issuers (for any $c \geq 0$ ), as these issuers have surplus-destroying projects that make it impossible for uninsured public market investors to break even.

Private Surplus

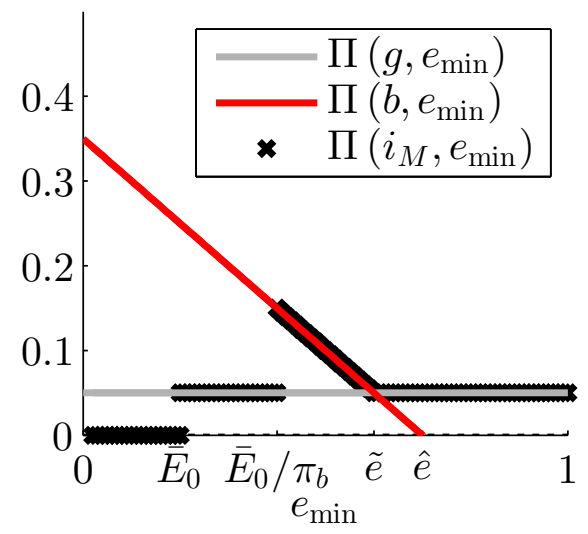

Funding Decisions

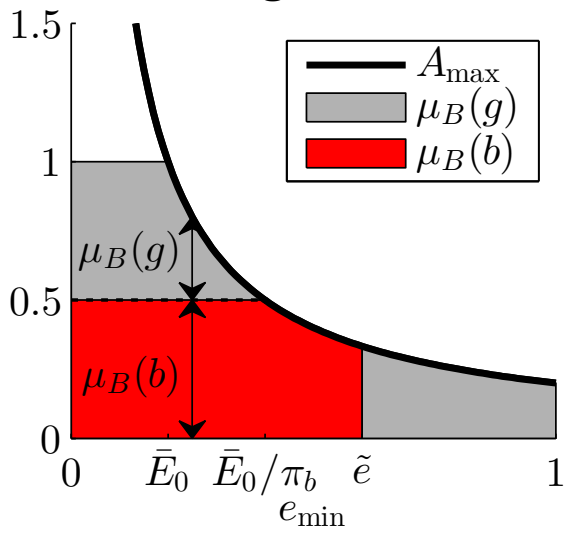

Welfare

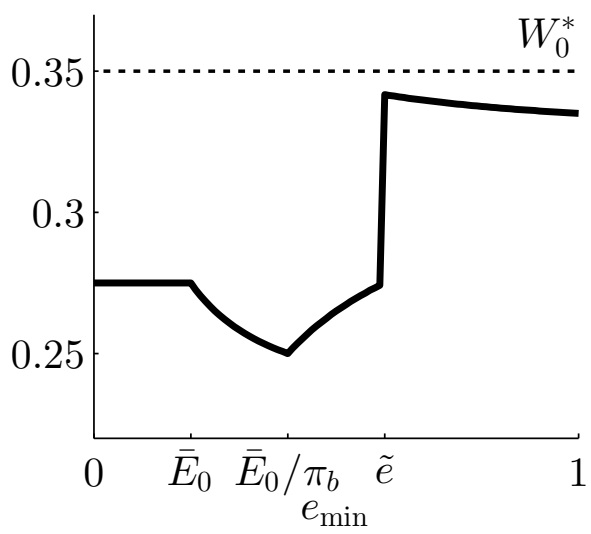

Loan Yields

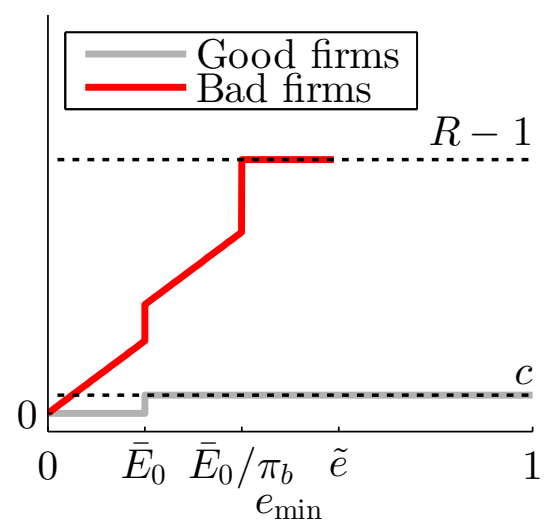

Figure 2. The figures illustrate the effect of varying equity ratio requirements, $e_{\min }$, on private surplus $\Pi$ for firm types (upper left panel), the funding decisions $\mu_{B}(i)$ by banks and capacity $A_{\max }$ (lower left panel), welfare $W_{0}$ (upper right panel) and the loan yields for firm types, i.e., $y(i)$, (lower right panel). The parameters of the economy are chosen as follows: $p_{H}=0.5, R=1.7, c=0.05, \pi_{g}=0.5, \bar{E}_{0}$ and $=0.2$. If $\bar{E}_{0}<e_{\min }<\bar{E}_{0} / \pi_{b}$, the good asset is the marginal funded asset. If $\bar{E}_{0} / \pi_{b}<e_{\min }<\tilde{e}$, the bad asset is the marginal funded asset.

Competition from public markets thus has an asymmetric effect on the surplus that banks can extract from good and bad issuers. Formally, as $\Pi\left(g, e_{\min }\right)=\min \left\{c, N P V_{g}\right\}$ is declining in $c$ for $c<R-1$, a lower comparative advantage vis-à-vis public market investors 
(lower $c$ ) reduces banks' maximum potential rents from funding good issuers. In contrast, banks' maximum surplus from funding bad issuers (see 23) is completely insensitive to the parameter $c$. Thus, competition only shifts $\Pi\left(g, e_{\min }\right)$ downwards.

As a result, increased efficiency of public markets can reverse banks' ranking of investment opportunities ${ }^{20}$ for values of $e_{\text {min }}$ below the ranking threshold $\tilde{e}$ banks rank surplus-destroying, bad issuers higher than surplus-generating, good issuers $\left(\Pi\left(b, e_{\min }\right)>\right.$ $\left.\Pi\left(g, e_{\min }\right)\right)$. In the region $e_{\min } \in\left[\bar{E}_{0}, \frac{\bar{E}_{0}}{e_{\min }}\right]$ banks thus reduce investment in good issuers in response to increases in capital requirements. As aggregate funding capacity shrinks, banks that previously funded good, safe issuers switch to bad, risky issuers. This effect would not arise in partial equilibrium where individual banks would always weakly reduce investment in bad issuers in response to increased capital ratio requirements. In general equilibrium, however, market clearing and banks' higher ranking of bad issuers imply that, if increased ratio requirements reduce the funding capacity of individual banks, more banks are needed to fund all bad issuers. In the region $e_{\min } \in\left[\bar{E}_{0}, \frac{\bar{E}_{0}}{e_{\min }}\right]$ higher capital requirements thus cause more banks to choose a risk-taking strategy.

Further, when capital requirements $e_{\text {min }}$ exceed the capacity threshold $\frac{\bar{E}_{0}}{\pi_{b}}$, banks' funding capacity becomes insufficient to fund all bad projects in the economy. The bad projects become marginal and banks can extract all the surplus. At this point, further increases in $e_{\text {min }}$ gradually reduce the banking sectors' investment in bad projects. All banks are, however, still fully exposed to bad issuers' bonds. Only after exceeding the ranking threshold $\tilde{e}$ banks rank good projects higher than bad projects - here, the skin-in-the game effect is finally strong enough. However, at that point, the banking sector's funding capacity is also insufficient to fund all good projects. First-best is therefore not achieved for any $e_{\min } \in[0,1]$.

\subsection{Equilibrium with Equity Issuances}

Banks' equity issuance decisions can be characterized in a fairly simple way: banks issue equity as long as the expected return on equity associated with a marginal investment exceeds the marginal cost of issuing equity, i.e., if $\bar{r}_{E}\left(e_{\min }, \bar{E}_{0}\right) \geq c_{E}$ (see Proposition 3 )

Figure 3 illustrates the effects of equity issuances by highlighting the deviations in equilibrium outcomes relative to the economy without equity issuances considered in section 4.1. In the left panel, we now scale private surplus, $\Pi\left(i, e_{\min }\right)$ by $e_{\min }$, since this pins

${ }^{20}$ Competition affects banks' ranking of issuers for a range of $e_{\min }$ as long as $c<p_{H}(R-1)$. 
down the expected rate of return on bank equity, when project $i$ is marginal (see Case 2 of Proposition 21). Equilibrium outcomes will only deviate (relative to the absence of equity issuances) in regions where equity monitoring cost $c_{E}$ (green line) lie below $\bar{r}_{E}\left(e_{\min }, \bar{E}_{0}\right)$ (black line). There are two regions where this is the case in the considered parameterization: in the first region, banks issue equity to expand good investment, which would have been constrained absent equity issuances. Equity issuances thus have a positive effect on welfare in this region (although bad projects are still funded in equilibrium). In the second region, only $\Pi\left(b, e_{\min }\right) / e_{\min }$ (red line) lies above $c_{E}$ (green line) so that banks use equity issuances only to expand bad investment. As a result, welfare declines due to banks' ability to issue public equity. Equity issuances thus do not per se resolve banks' moral hazard problem - in fact, they may even facilitate expansions in aggregate risk-taking.
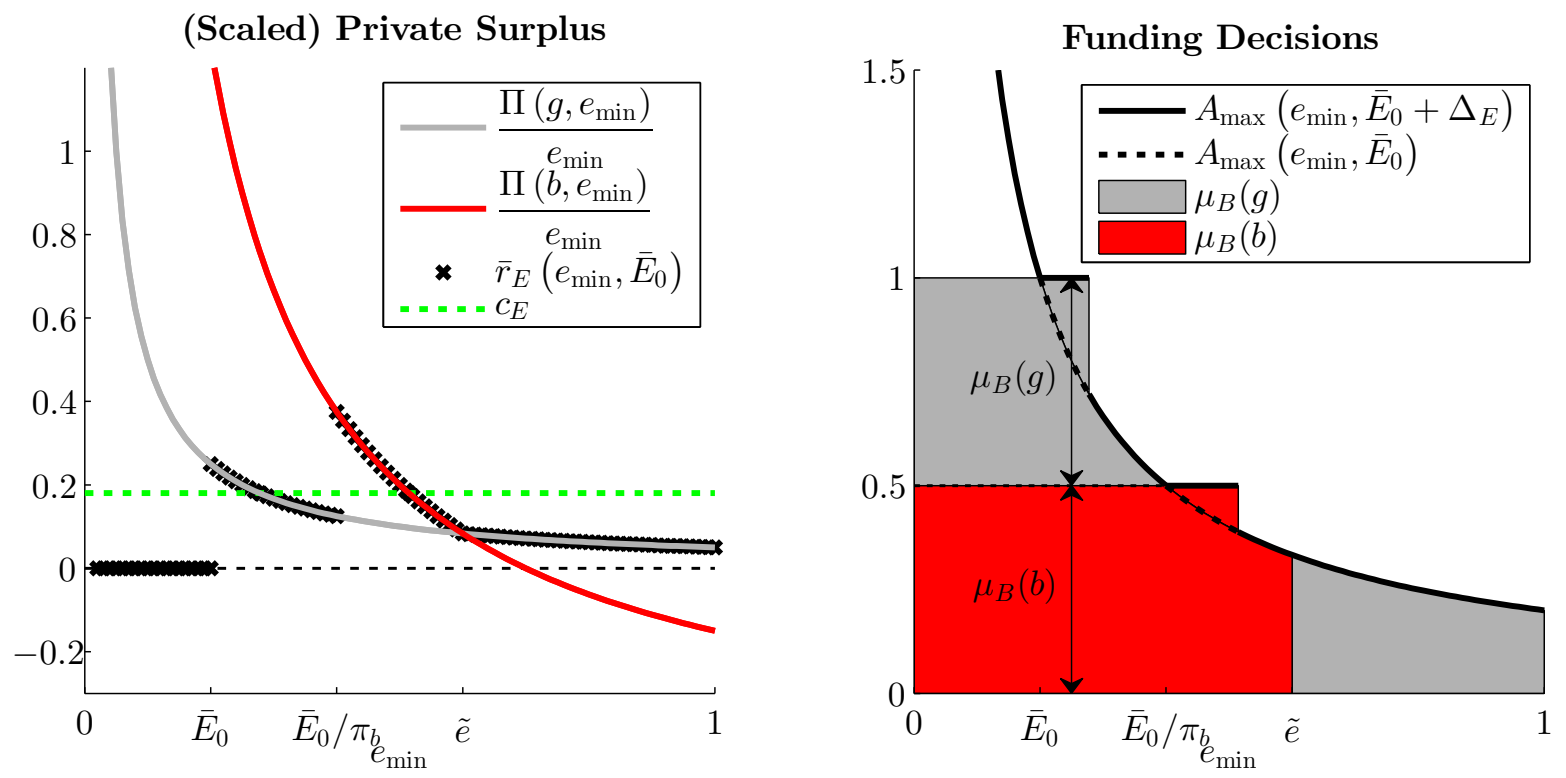

Figure 3. The left panel plots the effect of varying equity ratio requirements, $e_{\min }$, on private surplus scaled by $e_{\min }$ and the return on bank equity at the initial level of bank equity. The right panel plots the corresponding funding decisions $\mu_{B}(i)$ by banks and funding capacity $A_{\max }$ with and without equity issuance. Except for $c=0.05$, the parameters of the economy are as in Figure 2 $p_{H}=0.5, R=1.7$, $\pi_{g}=0.5, \bar{E}_{0}=0.2$ and $C_{E}=0.18$. If $\bar{E}_{0}<e_{\min }<\bar{E}_{0} / \pi_{b}$, the good asset is the marginal funded asset. In this region, banks will raise additional equity as long as $\frac{\Pi\left(g, e_{\min }\right)}{e_{\min }} \geq c_{E}$ (see left panel). If $\bar{E}_{0} / \pi_{b}<e_{\min }<\tilde{e}$, the bad asset is the marginal funded asset. Banks will raise additional equity as long as $\frac{\Pi\left(b, e_{\min }\right)}{e_{\min }} \geq c_{E}$. 


\section{Extensions}

In this section we discuss the robustness of our results to various alternative modeling assumptions.

Shadow banking. In the real world regulated financial institutions may move assets and liabilities off the regulated balance-sheet and into the less stringently regulated "shadow banking system." Such "off-balance sheet" or "shadow banking" activities typically involve some form of recourse and thus still expose the original financial institution to risks that can lead to default ${ }^{21}$ In terms of our model, financial institutions' ability to engage in such activities would imply weakly lower effective minimum equity capital constraints than the ones intended by the regulator. Given cross-sectional dispersion in various financial institutions' savviness in circumventing regulatory constraints, a common equity capital requirement would thus lead to cross-sectional differences in effective capital constraints.

To relate these observations to our model, suppose that a fraction of banks were able to lower their effective capital requirements to $e_{\min }^{\text {shaw }}<e_{\min }$ by transferring some of their risks off-balance sheet (in a regulatory accounting sense rather than in an economic sense). Our model then predicts that those institutions would take higher effective leverage and would invest in weakly riskier assets than banks that refrain from shadow banking activities. This follows from the fact that a lower effective leverage increases the value of the financing subsidy $\sigma\left(i, e_{\min }\right)$. Relating these observations to the pre-crisis period, one could also interpret less stringently regulated institutions as investment banks, which were initially not subject to the same regulation as commercial banks, but still had a significant probability of receiving government support in the event of financial distress.

Asset-specific comparative advantage. In reality, bank finance and public bond finance coexist; whereas certain parts of the cross-section of borrowers rely more heavily on bank finance, other types rely more on public bond markets. This coexistence suggests that there are cross-sectional differences in banks' comparative advantages across various

\footnotetext{
21 For example, asset-backed commercial paper (ABCP) conduits which precipitated the recent crisis were set up in most part by commercial banks, i.e., the regulated banking sector, as a way to get around capital requirements. Further, bank deposits moved to money market funds as a way of getting around Regulation $\mathrm{Q}$ on bank deposit rates. Yet many of the assets money market funds own are liabilities of the banking sector. Banks also purchased guarantees in the form of credit default swaps from A.I.G. Financial Products in order to reduce their capital requirements. However, the guarantor ultimately defaulted so that the risks came back to banks' balance sheets, revealing a lack of complete risk transfer.
} 
markets. In fact, public market investors might be more efficient than banks for certain classes (resulting in negative $c$ ). It is not the objective of our paper to empirically or theoretically determine for which types of borrowers banks have a comparative advantage in efficiency(see, e.g., Becker and Ivashina (2014) for related empirical evidence on substitution between bank and public bond finance). We note, however, that our model could easily accommodate security $k$ and borrower-specific $i$ comparative advantage. The private ranking of the banking sector is then determined according to

$$
\Pi_{k}\left(i, e_{\min }\right)=\max \left\{\min \left\{c_{k}(i), N P V(i)\right\}+\sum_{s \in \Sigma\left(i, e_{\min }\right)} p_{s}\left(1-e_{\min }-C_{s}(i)\right), 0\right\}
$$

Implications for optimal regulation and risk-weights. Following in spirit the literature on incomplete contracts. ${ }^{22}$ we have assumed that banks' activities (assets) are sufficiently complex so that the regulator could only rely on simple capital requirements. Yet, despite this restriction on the regulatory toolset, we derived sufficient conditions when first-best welfare could be achieved (see Lemma 4). However, when first-best welfare cannot be achieved with simple capital requirements, using additional signals as conditioning information may be useful.

If the regulator had access to perfect signals, she could micro-manage a bank's asset portfolio according to the $N P V$. Since, in reality, all additional signals, such as credit ratings, asset classifications, and accounting and market variables, are inherently noisy and do not even attempt to measure the risk a regulator is concerned about ${ }^{23}$ regulations can generally not be conditioned on all elements of banks' information sets. The resulting residual moral hazard problem is at the center of this study ${ }^{24}$ In addition, existing empirical and theoretical literature emphasizes that the regulatory use of various risk measures

22 See, e.g., Grossman and Hart $(1986)$, Bolton and Scharfstein (1990, 1996), Hart and Moore (1994. 1998).

23 Iannotta and Pennachi (2014) show theoretically and empirically that since credit ratings fail to capture systematic risk exposures banks have an incentive to invest in those securities with the highest aggregate risk exposures in a given ratings class. To address these shortcomings of ratings, the National Association of Insurance Commissioners (NAIC) recently replaced ratings with risk assessments by Pimco/BlackRock for the purpose of capital regulation. The new input is only used for for of U.S. insurance companies' holdings of non-agency mortgage-backed securities and measures expected losses of principal, very similar to ratings (see Becker and Opp (2013)).

${ }^{24}$ In an earlier version of this paper, we also explicitly modeled a strategic credit rating agency that evaluated issuers' riskiness. This model revealed that although ratings can be potentially helpful in reducing bank moral hazard, heavy regulatory reliance on ratings can also induce rating inflation, rendering capital regulation ineffective. 
may have feedback effects on their informational content 25

Nonetheless, our paper has concrete implications for the design of optimal risk-weights. First, risk should be measured by $\sigma$, which is a measure of borrowers' contributions to bank default risk. Second, optimal risk-weighted capital requirements depend not only on asset risk characteristics but also banks' comparative advantages in the financial system. Lower comparative advantage in a certain asset class increases incentives to engage in risk-taking (see 24). This feature of our model gives rise to "narrow banking" policies that make very high capital surcharges or even outright bans optimal in these asset classes ${ }^{26}$

\section{Conclusion}

In this paper we propose a tractable general equilibrium framework to analyze the effectiveness of bank capital regulations when a competitive banking sector also faces competition from public markets. Due to ex-post bailouts of banks' debtholders, the Modigliani-Miller theorem is violated, potentially making (socially excessive) debt financing privately optimal for banks. Thus, banks' value maximizing loan portfolios not only consider the social surplus they can extract from their borrowers but also the present value of transfers from tax payers. Competition from public markets has an asymmetric effect on these two sources of private surplus for banks: it naturally only limits banks' rents from lending to those borrowers that could actually be funded by uninsured public market participants. As a result, banks may be able to generate more private surplus from lending to high-risk borrowers that destroy social surplus than from lending to relatively safe borrowers that generate positive social surplus.

Our model shows that such competition can induce a non-monotonic relationship between regulatory capital requirements and banks' risk-taking. When aggregate funding capacity is constrained, profit maximization of banks may imply that banks drop safe, positive NPV borrowers rather than risky borrowers in response to system-wide increases in equity capital ratio requirements - as a result, the average bank can become riskier rather than safer. Interestingly, the ability of banks to raise additional equity may have

25 Bond, Goldstein, and Prescott (2010) and Goldstein and Bond (2014) highlight that when governments and bank supervisors make intervention decisions or corrective actions based on the information revealed by stock market prices, prices adjust to reflect this use and potentially become less revealing. Opp, Opp, and Harris (2013) show that ratings precision adjusts to the regulatory use of ratings and that regulatory reliance on ratings can be the cause of inflated and uninformative ratings.

${ }^{26}$ See Neuhann and Saidi (2014) for an empirical analysis of the cost of restricting the scope of banking activities. 
counterintuitive effects despite relaxing capacity constraints. Banks may lever up on the additional equity capital to expand risk-taking activities. We also show — in line with conventional wisdom - that when the banking sector possesses excess funding capacity, greater "skin-in-the-game" unambiguously lowers inefficient risk-taking and improves welfare.

Our analysis thus suggests that the effects of regulatory changes crucially depend on whether banks are constrained in funding privately profitable borrowers under the statusquo regulation. These capacity constraints likely vary with macro-economic conditions, implying that changes in capital requirements generally do not have an unambiguous effect on the riskiness of the banking sector.

In addition, our framework generates rich predictions on the distribution of surplus between financial institutions, public market investors, and borrowers. Since banks compete with each other, banks pass on their financing subsidies induced by bailouts to high-risk borrowers (unless bank capital is sufficiently scarce). As a result, yields on borrowers reflect downward biased assessments of default risk, in particular for borrowers with tail risk. Our framework thus provides an incentives-based explanation for artificially low yields on structured securities in the pre-crisis period and may explain why sophisticated, insured financial institutions were still holding a sizeable fraction of these securities.

\section{A Proofs}

Lemma 5 If Assumption 1 holds and $r_{D}=0$, a welfare-maximizing regulator bails out a defaulting bank regardless of the bank's portfolio $\left\{x_{i}\right\}$ and capital structure choice $e$.

Proof: Since $r_{D}=0$, the required bailout for a defaulting bank $\left(D_{0}>A_{0}\left(1+r_{A}^{s}\right)\right)$ is

$$
\begin{aligned}
B_{s} & =D_{0}-A_{0}\left(1+r_{A}^{s}\right) \\
& =A_{0}\left(-e-r_{A}^{s}\right),
\end{aligned}
$$

where the second line follows from $D_{0}=A_{0}(1-e)$. A bailout is welfare-enhancing if distress costs outweigh taxation costs, i.e., if

$$
\alpha A_{0}\left(1+r_{A}^{s}\right) \geq \tau A_{0}\left(-e-r_{A}^{s}\right)
$$

This condition holds for all $e$ and all portfolio choices if it holds for $e=0$ and $r_{A}^{s}$ being set to 
the worst possible loan portfolio realization, i.e., $r_{A}^{s}=\min _{i, s} r_{i}^{s}=\min _{i, s} C_{s}(i)-1=\underline{C}-1$.

\section{A.1 Proof of Lemma 1}

Proof: Let $r_{i}^{s}$ denote the return on asset $i$ in state $s$. To obtain marginal valuations we consider an $\varepsilon$-perturbation of the bank's asset portfolio such that state-dependent returns on assets are given by

$$
r_{A}^{s}(\varepsilon)=\varepsilon r_{i}^{s}+(1-\varepsilon) r_{A}^{s} \text {. }
$$

Banks maximize their equity value and thus require that asset $i$ is priced such that a marginal perturbation keeps the expected return on equity unchanged. For a bank with portfolio $x$ defaulting in states $\Sigma_{B}(x)$, the expected return on equity given the perturbation is given by:

$$
\bar{r}_{E}(\varepsilon)=\mathbb{E}\left[\frac{\varepsilon r_{i}^{s}+(1-\varepsilon) r_{A}^{s}}{e} \mid \Sigma_{B}^{\complement}(x)\right] \sum_{s \in \Sigma_{B}^{\complement}(x)} p_{s}-1 \sum_{s \in \Sigma_{B}(x)} p_{s} .
$$

Imposing that $\left.\frac{d \mathbb{E}\left[\bar{r}_{E}(\varepsilon)\right]}{d \varepsilon}\right|_{\varepsilon=0}=0$ then implies that the bank is willing to purchase a marginal unit of asset $i$ as long as the return on asset $i$ in the high state satisfies

$\mathbb{E}\left[r_{i}^{s} \mid \Sigma_{B}^{\complement}(x)\right]=\mathbb{E}\left[r_{A}^{s} \mid \Sigma_{B}^{\complement}(x)\right]$, or $1+\mathbb{E}\left[r_{i}^{s} \mid \Sigma_{B}^{\complement}(x)\right] \equiv \frac{\mathbb{E}\left[C F^{s}(i) \mid \Sigma_{B}^{\complement}(x)\right]}{P V_{B}(i \mid x)}=1+\mathbb{E}\left[r_{A}^{s} \mid \Sigma_{B}^{\complement}(x)\right]$. Solving the second equality for $P V_{B}(i \mid x)$ results in 15 .

\section{A.2 Proof of Proposition 1}

Proof: First, note that bank shareholder value maximization is akin to maximizing payments to all security holders. This is because debt holders obtain a fixed amount regardless. For a portfolio strategy $x(j)$ and leverage $e$, the contribution of borrower $i$ to cash flows for all bank security holders (equity and debt) is given by the present value of loan repayments and the contribution of borrower $i$ to the present value of bailout payments, given that a fraction $1-e$ of the project is financed by insured depositors who are bailed out in states $\Sigma_{B}(x(j))$, i.e.,

$$
\mathbb{E}\left(\min \left\{C_{s}(i)-1, y(i)\right\}\right)+\sum_{s \in \Sigma_{B}(x(j))} p_{s}\left[1-e-C_{s}(i)\right]
$$


Since $y(i)$ is taken as given, portfolio and leverage optimization, $x(j)$ and $e$, only affect the second term.

Optimum leverage Part I: We first determine the optimum leverage $e$ conditional on $x(j)$. Since feasible values of $e$ satisfy $e \geq e_{\min }$, the value of $\sum_{s \in \Sigma_{B}(x(j))} p_{s}\left[1-e-C_{s}(i)\right]$ is strictly smaller than $\sum_{s \in \Sigma_{B}(x(j))} p_{s}\left[1-e_{\min }-C_{s}(i)\right]$ as long as $\Sigma_{B}(x(j))$ is non-empty. Therefore for any portfolio strategy $x(j)$ such that $\Sigma_{B}(x(j)) \neq \emptyset, e=e_{\min }$ is strictly optimal (and otherwise weakly optimal). This completes the proof for the first part of statement 2). Let us therefore now assume that $e=e_{\min }$.

Optimum portfolio characteristics: For any bank portfolio $\Sigma_{B}(x(j)) \neq \Sigma\left(i, e_{\min }\right)$ the following relation holds

$$
\begin{aligned}
\sum_{s \in \Sigma_{B}(x(j))} p_{s}\left[1-e_{\min }-C_{s}(i)\right] & <\sum_{s} p_{s} \max \left\{1-e_{\min }-C_{s}(i), 0\right\} \\
& =\sum_{s \in \Sigma\left(i, e_{\min }\right)} p_{s}\left[1-e_{\min }-C_{s}(i)\right]
\end{aligned}
$$

This follows from the fact if $C_{s}(i) \gtrless 1-e$ and bank $j$ defaults in state $s$, then the contribution to the bailout guarantee in state $s$ is negative (positive), i.e., borrower $i$ reduces (increases) the subsidy by tax payers. Thus, only for a bank portfolio strategy $x(j)$ such that $\Sigma_{B}(x(j))=\Sigma\left(i, e_{\min }\right)$, borrower $i$ will contribute positively to the financing subsidy in all possible states (and negatively in no states). Profit maximization then implies statements 3) and 1) of the Proposition.

Optimum leverage Part II: We have already proved that $e=e_{\min }$ is strictly optimal for $\Sigma\left(i, e_{\min }\right)$ nonempty. Now suppose $\Sigma\left(i, e_{\min }\right)=\emptyset$, then the value of the bailout guarantee satisfies: $\sum_{s \in \Sigma\left(i, e_{\min }\right)} p_{s}\left[1-e_{\min }-C_{s}(i)\right]=0$. Now suppose that for this borrower the face value is set such that $\sum p_{s} \frac{\min \left\{C_{s}(i), y(i)\right\}-1}{e}>0$, and hence $\bar{r}_{E}>0$. Clearly, a bank can increase its expected return on equity as long as $e>e_{\min }$. Therefore, $e=e_{\min }$ if $\bar{r}_{E}>0$. If yields are set such that $\sum p_{s}\left[\min \left\{C_{s}(i)-1, y(i)\right\}\right]=0$, then a bank is indifferent among leverage choices. This completes the second part of statement 2). 


\section{References}

Acharya, V. V., P. Schnabl, and G. Suarez (2013): "Securitization without risk transfer," Journal of Financial Economics, 107(3), 515-536.

Admati, A. R., P. M. DeMarzo, M. F. Hellwig, and P. C. Pfleiderer (2011): "Fallacies, irrelevant facts, and myths in the discussion of capital regulation: Why bank equity is not expensive," Working paper series, Stanford University.

Adrian, T., AND H. S. Shin (2010): "Liquidity and leverage," Journal of Financial Intermediation, 19(3), 418-437.

Allen, F., E. Carletti, and R. Marquez (2011): "Credit Market Competition and Capital Regulation," Review of Financial Studies, 24(4), 983-1018.

Becker, B., And V. Ivashina (2013): "Reaching for yield in the corporate bond market," Unpublished working paper, Stockholm School of Economics and Harvard Business School.

(2014): "Cyclicality of credit supply: Firm level evidence," Journal of Monetary Economics, Elsevier, 62(C), 76-93.

BECKER, B., AND M. OpP (2013): "Regulatory reform and risk-taking: replacing ratings," Working Paper 19257, National Bureau of Economic Research.

Begenau, J. (2013): "Capital Requirements, Risk Choice, and Liquidity Provision in a Business Cycle Model," Unpublished working paper, Stanford.

Bernardo, A. E., ANd I. Welch (2013): "Leverage and preemptive selling of financial institutions," Journal of Financial Intermediation, 22(2), 123-151.

Bolton, P., And D. S. Scharfstein (1990): "A Theory of Predation Based on Agency Problems in Financial Contracting," American Economic Review, 80(1), 93-106.

(1996): "Optimal Debt Structure and the Number of Creditors," Journal of Political Economy, 104(1), 1-25.

Bond, P., I. Goldstein, And E. S. Prescott (2010): "Market-Based Corrective Actions," Review of Financial Studies, 23(2), 781-820.

Calomiris, C. W., and C. M. Kahn (1991): "The Role of Demandable Debt in Structuring Optimal Banking Arrangements," American Economic Review, 81(3), 497-513. 
DeAngelo, H., and R. M. Stulz (2013): "Liquid-Claim Production, Risk Management, and Bank Capital Structure: Why High Leverage is Optimal for Banks," Social Science Research Network Working Paper Series.

Diamond, D. W. (1984): "Financial Intermediation and Delegated Monitoring," Review of Economic Studies, 51(3), 393-414.

Diamond, D. W., and P. H. Dybvig (1983): "Bank Runs, Deposit Insurance, and Liquidity," Journal of Political Economy, 91(3), 401-19.

Diamond, D. W., and R. G. Rajan (2001): "Liquidity Risk, Liquidity Creation, and Financial Fragility: A Theory of Banking," Journal of Political Economy, 109(2), pp. 287-327.

Erel, I., T. Nadauld, and R. M. Stulz (2013): "Why Did Holdings of Highly Rated Securitization Tranches Differ So Much across Banks?," Review of Financial Studies.

Goldstein, I., And P. Bond (2014): "Government intervention and information aggregation by prices," The Journal of Finance.

Gornall, W., and I. Strebulaev (2013): "Financing as a Supply Chain: The Capital Structure of Banks and Borrowers," Unpublished working paper, Stanford.

Gorton, G., And G. Pennacchi (1990): "Financial Intermediaries and Liquidity Creation," Journal of Finance, 45(1), 49-71.

Grossman, S. J., and O. D. Hart (1986): "The Costs and Benefits of Ownership: A Theory of Vertical and Lateral Integration," Journal of Political Economy, 94(4), 691-719.

Harris, M., and A. Raviv (2014): "How to Get Banks to Take Less Risk and Disclose Bad News," Journal of Financial Intermediation.

Hart, O., And J. Moore (1994): "A Theory of Debt Based on the Inalienability of Human Capital," The Quarterly Journal of Economics, 109(4), 841-79.

(1998): "Default And Renegotiation: A Dynamic Model Of Debt," The Quarterly Journal of Economics, 113(1), 1-41.

Hennessy, C. A., and T. M. Whited (2007): "How Costly Is External Financing? Evidence from a Structural Estimation," Journal of Finance, 62(4), 1705-1745. 
Hoshi, T., And A. Kashyap (1999): "The Japanese Banking Crisis: Where Did It Come From and How Will It End?, Working Paper 7250, National Bureau of Economic Research.

(2001): Corporate Financing and Governance in Japan: The Road to the Future. Mass.: MIT Press.

Iannotta, G., And G. Pennachi (2014): "Ratings-Based Capital Regulation and Systematic Risk Incentives," Working paper, University of Illinois, Department of Finance.

James, C. (1991): "The Losses Realized in Bank Failures," Journal of Finance, 46(4), $1223-42$.

Kisin, R., and A. Manela (2013): "The Shadow Cost of Bank Capital Requirements," Unpublished working paper, Washington University, St. Louis.

Kydland, F. E., and E. C. Prescott (1977): "Rules Rather Than Discretion: The Inconsistency of Optimal Plans," Journal of Political Economy, University of Chicago Press, 85(3), 473-91.

Leland, H. E. (1994): "Corporate Debt Value, Bond Covenants, and Optimal Capital Structure," The Journal of Finance, 49(4), 1213-1252.

Mehran, H., V. V. Acharya, and A. V. Thakor (2013): "Caught between Scylla and Charybdis? Regulating Bank Leverage When There is Rent Seeking and Risk Shifting," Working paper, ECGI - Finance Working Paper No. 365/2013.

Moreira, A., And A. Savov (2013): "The Macroeconomics of Shadow Banking," Unpublished working paper, Yale University and NYU Stern.

Neuhann, D., And F. SAidi (2014): "The Firm-level Real Effects of Bank-scope Deregulation: Evidence from the Rise of Universal Banking," Working paper, University of Pennsylvania and Cambridge University.

Nguyen, T. T. (2014): "Bank Capital Requirements: A Quantitative Analysis," Working paper, The Wharton School.

Opp, C. C., M. M. Opp, And M. Harris (2013): "Rating agencies in the face of regulation," Journal of Financial Economics, 108(1), 46-61.

Ordonez, G. (2014): "Sustainable Shadow Banking," Unpublished working paper, University of Pennsylvania. 
Parlour, C. A., and U. Rajan (2001): "Competition in Loan Contracts," American Economic Review, 91(5), 1311-1328.

Pennacchi, G. (2006): "Deposit insurance, bank regulation, and financial system risks," Journal of Monetary Economics, 53(1), 1-30.

Petersen, M. A., and R. G. Rajan (1995): "The Effect of Credit Market Competition on Lending Relationships," The Quarterly Journal of Economics, 110(2), 407-43.

Plantin, G. (2014): "Shadow Banking and Bank Capital Regulation," Unpublished working paper, Toulouse School of Economics.

Rajan, R. G., and L. Zingales (2001): "Financial Systems, Industrial Structure, and Growth," Oxford Review of Economic Policy, 17(4), 467-482.

Rappoport, V., D. Paravisini, and P. Schnabl (2014): "Comparative Advantage and Specialization in Bank Lending," Discussion paper, London School of Economics and New York University.

Stiglitz, J. E., And A. Weiss (1981): "Credit Rationing in Markets with Imperfect Information," American Economic Review, 71(3), 393-410. 